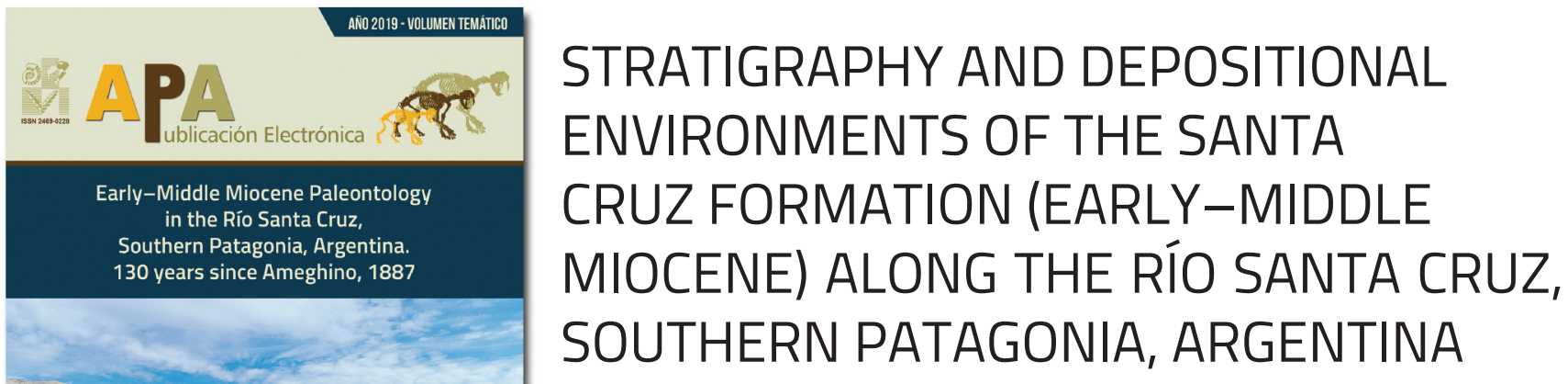

JOSÉ I. CUITIÑO'

JUAN C. FERNICOLA2,3

M. SOL RAIGEMBORN ${ }^{4}$

VERÓNICA KRAPOVICKAS 5

IInstituto Patagónico de Geología y Paleontología, Centro Nacional Patagónico, Centro Científico Tecnológico del Consejo Nacional de Investigaciones Científicas y Técnicas (IPGP, CCT CONICET-CENPAT). Boulevard Brown 2915, U9120ACD Puerto Madryn, Chubut, Argentina.

¿Sección Paleontología de Vertebrados, Museo Argentino de Ciencias Naturales "Bernardino Rivadavia". Av. Ángel Gallardo 470, 1405DJR Ciudad Autónoma de Buenos Aires, Argentina.

${ }^{3}$ Universidad Nacional de Luján, Departamento de Ciencias Básicas. Ruta 5 y Av. Constitución, 6700 Luján, Buenos Aires, Argentina.

${ }^{4}$ Centro de Investigaciones Geológicas, Consejo Nacional de Investigaciones Científicas y Tecnológicas-Universidad Nacional de La Plata (CIG, CONICET-UNLP). Diagonal 113 275, 1904 La Plata, Argentina.

5 Instituto de Estudios Andinos Don Pablo Groeber, Departamento de Ciencias Geológicas, Facultad de Ciencias Exactas y Naturales, Universidad de Buenos AiresConsejo Nacional de Investigaciones Científicas y Técnicas (IDEAN, CONICET-UBA). Intendente Güiraldes 2160, Ciudad Universitaria, Pabellón 2, C1428EHA Ciudad Autónoma de Buenos Aires, Argentina.

Recibido: 5 de abril 2019 - Aceptado: 27 de julio 2019

Para citar este artículo: José I. Cuitiño, Juan C. Fernicola, M. Sol Raigemborn, and Verónica Krapovickas (2019). Stratigraphy and depositional environments of the Santa Cruz Formation (Early-Middle Miocene) along the Río Santa Cruz, Southern Patagonia, Argentina. Publicación Electrónica de la Asociación Paleontológica Argentina 19 (2): 14-33.

Link a este artículo: http://dx.doi.org/10.5710/PEAPA.27.07.2019.294

DESPLAZARSE HACIA ABAJO PARA ACCEDER AL ARTÍCULO

Asociación Paleontológica Argentina Maipú $6451^{\circ}$ piso, C1006ACG, Buenos Aires República Argentina Tel/Fax (54-11) 4326-7563 Otros artículos en Publicación Electrónica de la APA 19(2): Web: www.apaleontologica.org.ar

\section{J.C. Fernícola et al.}

HISTORICAL BACKGROUND FOR A REVISION OF THE PALEONTOLOGY OF THE SANTA CRUZ FORMATION (EARLY-MIDDLE MIOCENE) ALONG THE RÍO SANTA CRUZ, PATAGONIA, ARGENTINA

\section{P. Muzzopappa}

CALYPTOCEPHALELLA (ANURA, AUSTRALOBATRACHIA) REMAINS FROM RÍO SANTA CRUZ (EARLY-MIDDLE MIOCENE, SANTA CRUZ FORMATION), SANTA CRUZ PROVINCE, ARGENTINA
J.C. Fernicola, S.F. Vizcaíno

CINGULATES (MAMMALIA, XENARTHRA) OF THE SANTA CRUZ FORMATION (EARLY-MIDDLE MIOCENE, BURDIGALIAN) FROM THE RÍO SANTA CRUZ, ARGENTINE PATAGONIA 


\title{
STRATIGRAPHY AND DEPOSITIONAL ENVIRONMENTS OF THE SANTA CRUZ FORMATION (EARLY-MIDDLE MIOCENE) ALONG THE RÍO SANTA CRUZ, SOUTHERN PATAGONIA, ARGENTINA
}

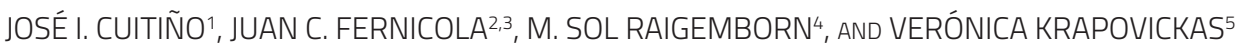

IInstituto Patagónico de Geología y Paleontología, Centro Nacional Patagónico, Centro Científico Tecnológico del Consejo Nacional de Investigaciones Científicas y Técnicas (IPGP, CCT CONICET-CENPAT). Boulevard Brown 2915, U9120ACD Puerto Madryn, Chubut, Argentina. jcuitino@cenpat-conicet.gob.ar

25ección Paleontología de Vertebrados, Museo Argentino de Ciencias Naturales "Bernardino Rivadavia". Av. Ángel Gallardo 470, 1405DJR Ciudad Autónoma de Buenos Aires, Argentina.jctano@macn.gov.ar

${ }^{3}$ Universidad Nacional de Luján, Departamento de Ciencias Básicas. Ruta 5 y Av. Constitución, 6700 Luján, Buenos Aires, Argentina.

${ }^{4}$ Centro de Investigaciones Geológicas, Consejo Nacional de Investigaciones Científicas y Tecnológicas-Universidad Nacional de La Plata (CIG, CONICET-UNLP). Diagonal 113 275, 1904 La Plata, Argentina.msol@cig.museo.unlp.edu.ar

5 Instituto de Estudios Andinos Don Pablo Groeber, Departamento de Ciencias Geológicas, Facultad de Ciencias Exactas y Naturales, Universidad de Buenos AiresConsejo Nacional de Investigaciones Científicas y Técnicas (IDEAN, CONICET-UBA). Intendente Güiraldes 2160, Ciudad Universitaria, Pabellón 2, C1428EHA Ciudad Autónoma de Buenos Aires, Argentina.

\begin{abstract}
The Santa Cruz Formation is an Early-Middle Miocene terrestrial sedimentary succession widely distributed in southern Patagonia. Particularly, it is exposed along the southern margin of the Río Santa Cruz valley where the sedimentological and stratigraphical features are described for three localities. From east to west these localities are: Barrancas Blancas, Segundas Barrancas Blancas and Yaten Huageno. The facies analysis permits us to identify three associations, representing deposition in 1) low-energy floodplains; 2) crevasse splays and sheet floods; and 3) fluvial channels. The three localities are chronologically equivalent and represent accumulation in an aggradational lowgradient fluvial system that drained towards the east and northeast from the Patagonian Andes to the Atlantic sea. Abundant pedogenic features and some trace fossils are consistent with a temperate subhumid climate and in part, a grassland environment.
\end{abstract}

Key words. Burdigalian. Sedimentology. Fluvial system. Paleosol. Austral Basin.

Resumen. ESTRATIGRAFÍA Y AMBIENTES DE SEDIMENTACIÓN DE LA FORMACIÓN SANTA CRUZ (MIOCENO TEMPRANO-MEDIO) EN EL RÍO SANTA CRUZ, PATAGONIA AUSTRAL, ARGENTINA. La Formación Santa Cruz consiste en una sucesión de sedimentos continentales del Mioceno Temprano-Medio que se encuentran ampliamente distribuidos en la Patagonia austral. Se describen los atributos sedimentológicos y estratigráficos de tres localidades a lo largo del Río Santa Cruz. De este a oeste estas localidades son: Barrancas Blancas, Segundas Barrancas Blancas y Yaten Huageno. El análisis de facies permitió definir tres Asociaciones que representan acumulación en 1) planicies de inundación; 2) lóbulos de desbordamiento y crecidas en manto; y 3) canales fluviales. Las tres localidades son cronológicamente equivalentes y representan acumulación en un sistema fluvial de bajo gradiente con alta agradación, el cual drenaba hacia el este y noreste desde los Andes Patagónicos hasta la plataforma. Los rasgos de los paleosuelos, más algunas trazas fósiles reconocidas, sugieren un clima templado subhúmedo y en parte, una planicie herbácea.

Palabras clave. Burdigaliense. Sedimentología. Sistema fluvial. Paleosuelo. Cuenca Austral.

The Santa Cruz Formation (SCF) is an Early-Middle Miocene continental sedimentary succession that is distributed in a large area of southern Patagonia within the Austral-Magallanes Basin. This unit represents an important record for Burdigalian-early Langhian high-latitude paleoenvironments, paleoclimates, and terrestrial ecosystems of the Southern Hemisphere (e.g., Vizcaíno et al., 2012; Cuitiño et al., 2019). Early expeditions along the Río Santa Cruz valley summarized by Vizcaíno et al. (2013) and Fernicola et al. (2019a) noted the abundance and diversity of terrestrial fossil vertebrates from the sedimentary strata of the valley margins; the rich collections formed the basis for the Santacrucian South American Land Mammal Age (SALMA; Pascual et al., 1965; Marshall et al., 1983; Fernicola et al., 2014 
and references therein). Currently, the stratigraphy, chronology, sedimentology and paleontology of the SCF is best known for its exposures along the Atlantic coast of southeast of the Province of Santa Cruz (e.g., Tauber, 1999; Vizcaíno et al., 2012; Raigemborn et al., 2018a,b; Zapata, 2018; Trayler et al., 2019). Only recently has interest in the SCF of the Río Santa Cruz area increased, in part prompted by the beginning of a project for the construction of two dams in the Río Santa Cruz valley and the threat of subsequent flooding of fossiliferous outcrops. This resulted in some recent scientific contributions (Fernicola et al., 2014; Cuitiño et al., 2016) as well as the geology, stratigraphy, taxonomy, systematics, biostratigraphy, and paleoecology results presented in this Thematic Volume.

In this contribution we present new sedimentological and stratigraphic data obtained after revisiting some of the best exposures of the SCF along the southern margin of the Río Santa Cruz valley, with two main objectives. First, we aim to reconstruct the general depositional environment for the SCF in the Río Santa Cruz valley, and to compare it to other better known exposures of the unit. Second, we aim to provide a detailed stratigraphic context for the large number of fossils collected in this area.

\section{GEOLOGIC SETTING}

The Austral-Magallanes Basin is the southernmost basin of South America (Fig. 1.1) and its sedimentary record starts in the Early Cretaceous. Three main tectonic phases can be recognized for this basin: 1) a synrift phase occurred during the Late Jurassic-Early Cretaceous; 2) a sag phase occurred during the Early Cretaceous; and 3) a retroarc foreland stage occurred during the latest Cretaceous to Cenozoic (e.g., Biddle et al., 1986; Sachse et al., 2016). The sedimentary units outcropping in the Río Santa Cruz valley correspond to the younger part of the foreland stage and are thought to be strongly controlled by the Andean tectonics and arc volcanism (Fosdick et al., 2013; Cuitiño et al., 2016; Ghiglione et al., 2016; Parras and Cuitiño, 2018).

The Río Santa Cruz is one of the largest rivers of Patagonia. It flows through an incised deep and broad valley stretching $230 \mathrm{~km}$ from west to east, which was excavated during a relative sea level fall in the Quaternary. The river originates close to the Andean foothills in the eastern margin of Lago Argentino and ends in the Río Santa Cruz estuary that discharges in the Atlantic Ocean (Fig. 1.2-3). Along the valley margins, three Miocene sedimentary units of the Austral Basin can be recognized: (1) the shallow marine Early Miocene Estancia 25 de Mayo -previously named as Centinela Formation; Cuitiño and Scasso (2010)-, (2) the Monte León Formation (Sacomani and Panza, 2011; Parras and Cuitiño, 2018), and (3) the terrestrial Early-Middle Miocene Santa Cruz Formation (Tauber et al., 2008; Sacomani and Panza, 2011; Cobos et al., 2014; Fernicola et al., 2014; Cuitiño et al., 2016). A thin veneer of terrace conglomerates of Late Miocene to Quaternary age covers most of the study area (Sacomani and Panza, 2011; Cobos et al., 2014; Fig. 1).

The age of the SCF is well dated radiometrically. For the coastal zone of southeast of the Province of Santa Cruz the age of the unit is bracketed by means of $A r^{39} / \mathrm{Ar}^{40}$, high precision zircon $\mathrm{U} / \mathrm{Pb}$, and sedimentation rate estimations between 17.8 and 16 Ma (Burdigalian; Tejedor et al., 2006; Perkins et al., 2012; Trayler et al., 2019), whereas in the Río Santa Cruz valley the unit is dated by means of U/Pb on zircons and sedimentation rate estimations between $\sim 17.45$ and 15.6 Ma (Burdigalian-early Langhian; Cuitiño et al., 2016).

Beyond the Río Santa Cruz valley, the SCF and equivalent units are distributed in a wide area within the AustralMagallanes Basin (Fernicola et al., 2014, fig. 1; Fig. 1.2). It crops out along the foothills of the Andes from the Meseta Cosmelli in Aysén (Chile) (Ugalde et al., 2015; Encinas et al., 2019) and Lago Posadas regions ( 400 and 300 km to the northwest, respectively), where it is time equivalent to the Río Zeballos Group (Cuitiño et al., 2019; Aramendía et al., in press), and south of this area up to the Río Turbio region ( 200 km to the southwest; Fig. 1.2). It is also present in the central Santa Cruz Province near Gobernador Gregores and Lago Cardiel ( 150 km to the north). Several good exposures occur in the southern of the Province of Santa Cruz (Fig. 1.2), including the Río Chalía (= Sheuhen) (Vizcaíno et al., 2018) and the coastal zone between the Monte León National Park and the Río Gallegos estuary (Bown and Fleagle, 1993; Tauber, 1999; Matheos and Raigemborn, 2012; Raigemborn et al., 2015, 2018a,b; Zapata, 2018). The southernmost counterpart for the SCF is the Cullen Formation, located 

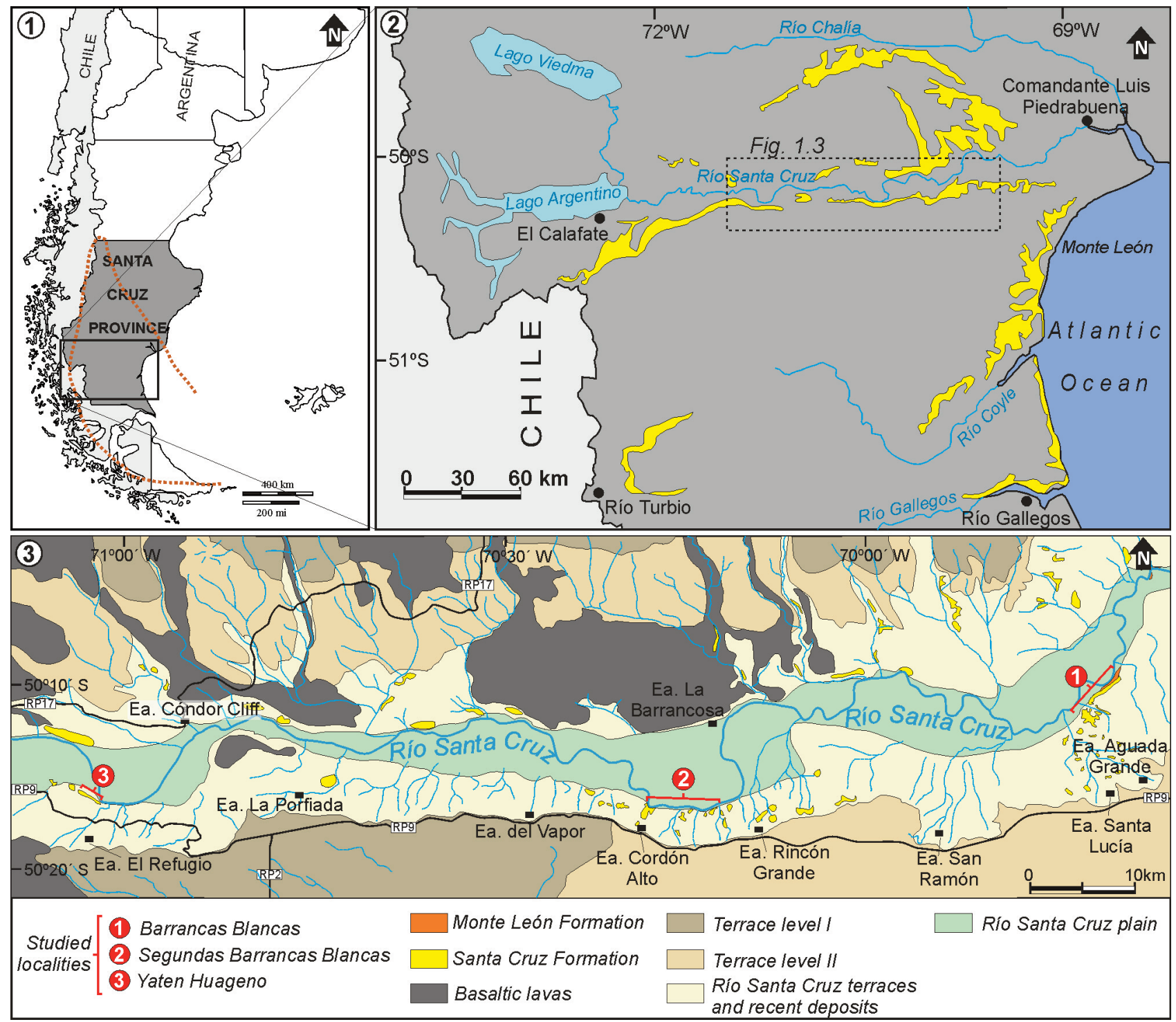

Figure 1. Geographic and geologic context for the studied outcrops. 1, regional location map showing the position of the study area. The boundary of the Austral-Magallanes Basin is highlighted in dotted red line. 2, Map of southern Santa Cruz province showing the distribution of the SCF outcrops (in yellow). The dashed-lined box indicates the location of the studied localities. 3, Detailed geologic map of the Río Santa Cruz valley and the localities studied in this work. Modified after Sacomani and Panza (2011) and Cobos et al. (2014).

$\sim 300 \mathrm{~km}$ to the southeast in the northern part of the Tierra del Fuego Island (Olivero et al., 2015; Bargo et al., 2018).

\section{METHODS}

This work is based on data collected in the field, including stratigraphic, sedimentological, macropedological and ichnological observations. The SCF crops out in both the north and south margins of the Río Santa Cruz valley. The three main localities of the southern margin are here described, which correspond to those visited in 1887 by Carlos Ameghino, and recently revisited, as described in Fernicola et al. (2014), with new dates presented in Cuitiño et al. (2016). From east to west they are (Fig. 1.3): Barrancas Blancas, within the boundaries of the Estancia Aguada Grande (EAG) and Estancia Santa Lucía (ESL); Segundas Barrancas Blancas, in the Estancia Cordón Alto (ECA) and 
Estancia El Tordillo (EET); and Yatén Huageno, in the Estancia El Refugio (Fig. 1.3).

The base and top of SCF exposures, as well as guide level elevations, were measured with conventional GPS devices taking care of recording only with the maximum available altitude accuracy. When possible, guide levels such as tuffs or distinctive yellow layers were followed in the field for several kilometers to check their validity as correlation horizons. We logged each outcrop using a Jacob Staff. Sedimentological descriptions include grain-size, primary sedimentary structures, bed thickness and geometry were noted. Paleosol macro pedofeatures noted include structure, mottles, nodules, color, slickensides, root traces, as well as body and other trace fossils (following Retallack, 2001). Colors were described according to the Geological Rock Color Chart (2009). Ages for the base and top of exposures were estimated using the available U/Pb ages and a sedimentation rate of $150 \mathrm{~m} /$ Ma estimated by Cuitiño et al. (2016), which is roughly coincident with average sedimentation rates of 158 m/Ma obtained by Trayler et al. (2019) for the SCF in the coastal zone by means of high precision geochronology. In addition, these values are very close to the sedimentation rate calculated by Sachse et al. (2016) for the times of deposition of the SCF in all the Austral Basin (170 m/Ma). Names and numerical ages for formal chronostratigraphic stages are taken from the International Chronostratigraphic Chart 2018/07.

\section{DEPOSITIONAL ENVIRONMENTS}

The sedimentological descriptions of the SCF in all the studied sections were the basis for defining a set of facies representing the main depositional processes (Tab. 1). These were grouped in Facies Associations (FAs) representing depositional sub-environments.

TABLE 1 - List of sedimentary facies defined in this work with their distinctive features

\begin{tabular}{|c|c|c|c|c|}
\hline $\begin{array}{l}\text { Facies } \\
\text { Code }\end{array}$ & Lithology & $\begin{array}{l}\text { Physical Sedimentary } \\
\text { Structures }\end{array}$ & Other features & Depositional process \\
\hline Sh & $\begin{array}{l}\text { Fine to medium sandstones, } \\
\text { well sorted. Gray to light gray. } \\
\text { Intraclasts and pumice common }\end{array}$ & $\begin{array}{l}\text { Plane-parallel and low-angle } \\
\text { lamination }\end{array}$ & - & $\begin{array}{l}\text { Tractive deposits formed through } \\
\text { upper flow regime plane bed }\end{array}$ \\
\hline St & Medium to coarse sandstones & $\begin{array}{l}\text { Trough cross-bedding. Occa- } \\
\text { sionally with pumice or intra- } \\
\text { clast particles on the foresets }\end{array}$ & $\begin{array}{l}\text { Common reddish to brownish } \\
\text { carbonate concretions }\end{array}$ & $\begin{array}{l}\text { Migration of 3D subaqueous } \\
\text { dunes within fluvial channels }\end{array}$ \\
\hline$S p$ & Medium to coarse sandstones & Planar cross-bedding. & - & Migration of 2D subaqueous dunes \\
\hline$S m$ & $\begin{array}{l}\text { Very fine to medium sandstones. } \\
\text { Abundant pyroclastic material }\end{array}$ & Structureless & $\begin{array}{l}\text { Common root traces. } \\
\text { Occasional decapod burrows. }\end{array}$ & $\begin{array}{l}\text { Tractive deposits subsequently } \\
\text { modified by soil forming processes }\end{array}$ \\
\hline Sr & Fine sandstones & $\begin{array}{l}\text { Ripple lamination. Usually } \\
\text { observed climbing ripples }\end{array}$ & - & $\begin{array}{l}\text { Deposition by tractive currents } \\
\text { by current ripple migration }\end{array}$ \\
\hline$F p$ & $\begin{array}{l}\text { Siltstone and mudstone, with } \\
\text { subordinate fine sandstone. } \\
\text { Usually greenish or gray }\end{array}$ & $\begin{array}{l}\text { Structureless. Remains of } \\
\text { plane-parallel or current } \\
\text { ripple lamination. }\end{array}$ & $\begin{array}{l}\text { Common root traces. Scarce mottles, } \\
\text { slickensides, nodules, cutans, peds, } \\
\text { rhizoconcretions, organic matter } \\
\text { remains. Scarce invertebrate trace } \\
\text { fossils and coprolites. }\end{array}$ & $\begin{array}{l}\text { Settling from suspension of fine } \\
\text { sediments in low energy environ- } \\
\text { ments and subsequent modification } \\
\text { by soil processes }\end{array}$ \\
\hline Fl & Silt and clay & Plane-parallel lamination & Scarce leaf remains. & $\begin{array}{l}\text { Settling from suspension of fine } \\
\text { sediments in low energy environ- } \\
\text { ments. Lamination produced by } \\
\text { fluctuating energy conditions }\end{array}$ \\
\hline$T m$ & $\begin{array}{l}\text { Medium to very fine tuffs. } \\
\text { White to light yellow or light pink }\end{array}$ & Structureless & $\begin{array}{l}\text { Abundant in-situ fossil } \\
\text { vertebrates. Scarce root traces }\end{array}$ & $\begin{array}{l}\text { Ash fallout deposits with subsequent } \\
\text { reworking by fluvial and pedogenic } \\
\text { processes. }\end{array}$ \\
\hline
\end{tabular}




\section{FA1- Floodplain deposits with paleosols}

Description. FA1 is dominant throughout the SCF and is composed of grayish yellow (5Y 8/4), light greenish gray (5GY 8/1) and yellowish gray (5Y 7/2) mudstones, siltstones and light gray very fine to fine sandstones usually lacking any primary sedimentary structure (facies Fp, Sm; Fig. 2.1). A variable degree of intermingled tuffaceous material (facies Tm) like sparse white (N9) to very light gray (N8) thin tuff layers are also observed (Fig. 2.1). Tabular beds of different colorations show large lateral extension, giving the stratified aspect to the unit. Although some layers show delicate parallel laminations (facies Fl; Fig. 2.2), other primary sedimentary structures are hardly observed. In some cases laminated mudstones show poorly preserved oxidized
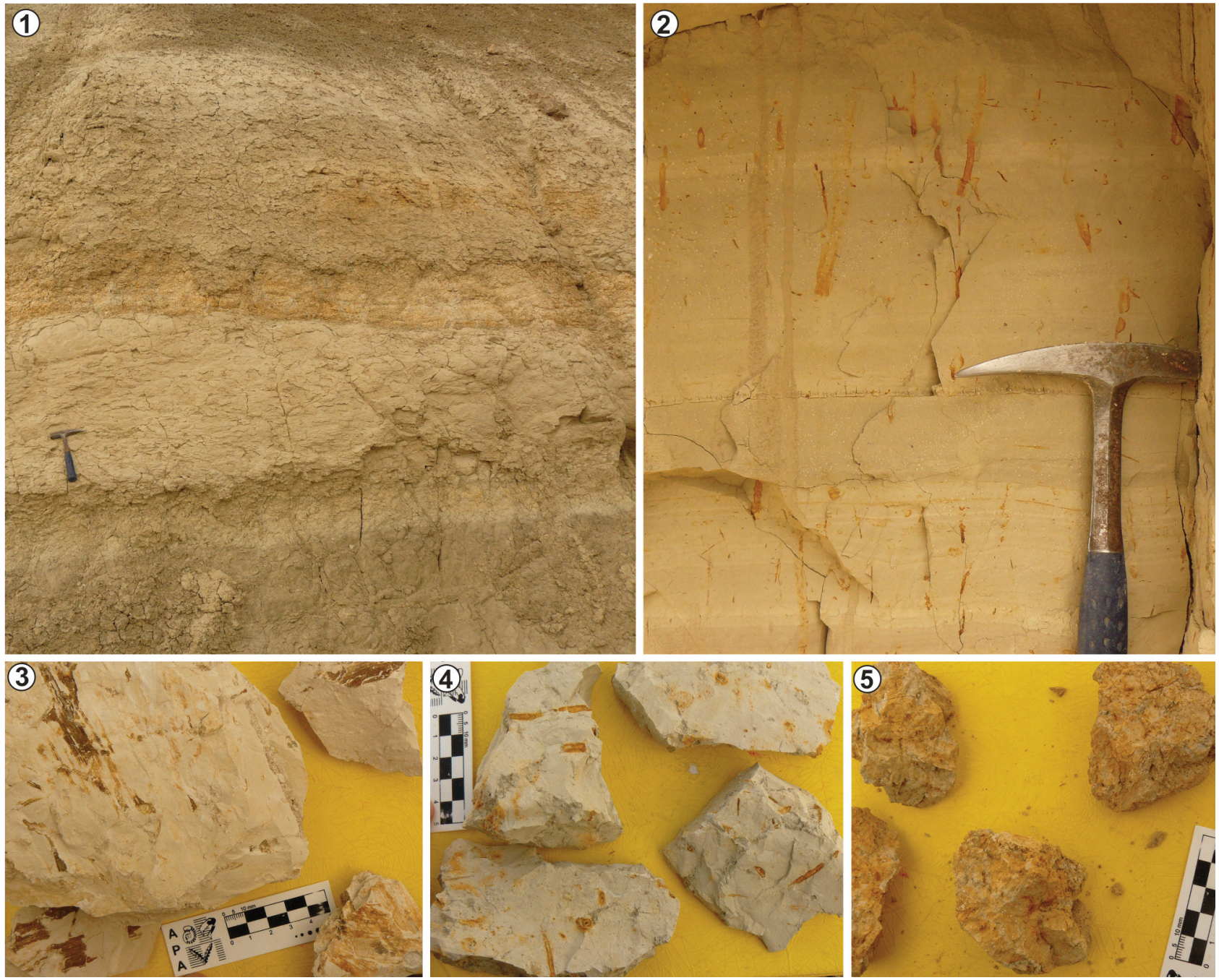

(6)

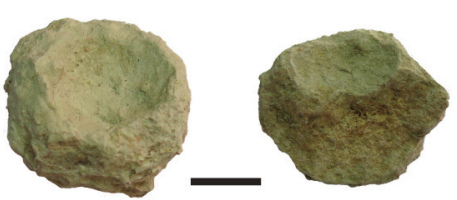

(7)

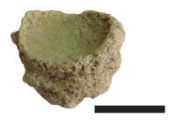

(8)

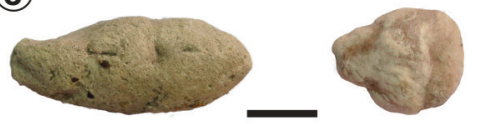

Figure 2. Different features of Facies Association 1 deposits. 1, succession of structureless strata composed of pedogenically-modified fine tuffaceous sandstones and mudstones. 2, Detail of laminated siltstones and mudstones with different types of orange-colored root traces. 3, Plant remains preserved on lamination planes of mudstone. 4, Detail of angular to subangular blocky peds with ferric delicate and haloed root traces. 5, Detail of subangular blocky to granular peds with abundant root traces and mottles. 6, Fragments of Coprinisphaera isp. 7, Feoichnus challa. 8, Coprolites. Scale bars for 6,7 and $8=1 \mathrm{~cm}$. 
leaf impressions on the lamination planes (Fig. 2.3), some of them tentatively assigned to Nothofagus Blume (1851) (Roberto Pujana, personal communication 2018). Pedogenic features are abundant in this FA (Fig. 2.2, 2.4-5), being dominated by very pale brown (10YR 8/2) to moderate yellowish brown (10YR 5/4) ferric and delicate root traces -following the classification of Krapovickas (2012)-. Usually these root traces show dark yellowish orange (10YR 6/6) to light brown (5YR 5/6) haloes -i.e., haloed-root traces sensu Krapovickas (2012)- (Fig. 2.4-5). Scarce trace fossils, such as Feoichnus challa Krause et al., 2008 (Fig. 2.7) and fragments of Coprinisphaera isp. (Fig. 2.6), and scarce coprolites (Fig. 2.8) are recorded. Organic matter, slickensides, ferrous and calcareous nodules, calcareous rhizoconcretions, and mottling are also observed (Fig. 2.5). In general, these pedogenically-modified beds show no evidence of soil horizonation and peds. However, occasionally soil horizons are recognized showing cutans, and a blocky to granular structures (Fig. 2.4-5).

Interpretation. The fine-grained nature of these deposits suggests low-energy environments of deposition. Abundant rhizoliths and other pedogenic features suggest subaerial exposure followed by plant colonization during periods of relative landscape stability that allowed pedogenesis. This is typical of distal fluvial floodplains, which receive sporadic influxes of sediment during flooding episodes with subsequent periods of non-deposition and soil development. Laminated mudstones are interpreted to be deposited in small ponds in the floodplain in which the preservation of leaf impressions took place under acid and oxidizing conditions.

The abundance of small diameter root traces would suggest colonization of the substrate by grasses, herbs, and shrubs (Retallack, 2001; Catena et al., 2016; Raigemborn et al., 2018b). However, we do not rule out the coexistence of this plant community with trees (based on the presence of leaves of Nothofagus in this FA) and/or palms indicating mixed environments involving open areas and patches of trees/palms, as has been described in similar paleosols of the SCF southeast of the study area (e.g., Raigemborn et al., $2018 a, b)$. In this context, the record of Coprinisphaera and Feoichnus are frequently but not exclusively preserved on grassland environments. These features are typical of open vegetated grassland-like soils, which could develop under subhumid to semiarid climates (Retallack, 2001; Catena et al., 2016; Raigemborn et al., 2018b). Particularly, granular structures are typically seen in wooded grassland soils (Retallack, 2001; Stoops et al., 2010). Reduced hues in the matrix paleosols indicate iron-depletion (e.g., Kraus and Hasiotis, 2006). However, the red and brown colors of the ferric root traces result from iron oxides, probably hematite, and represent better-oxidized areas where the Fe was reprecipitated (e.g., Kraus and Hasiotis, 2006). Fe-nodules indicate redox-cycles; haloed root traces, slickensides, mottling and calcareous features suggest well-drained conditions and seasonal rainfall. Remains of organic matter in paleosols could be preserved under wet conditions (Buol et al., 2011), and cutans (i.e., clay-coatings) are signs of improved soil-drainage (Ashley and Driese, 2000). In combination, these features are evidence of fluctuating soil moisture. Paleosols with lack of horizonation and peds, and preservation of relict sedimentary structures as those of the SCF, are considered as very weakly/weakly-developed paleosols, which resemble paleo-Entisols and -Inceptisols present in other sections of the SCF outside the study area (Raigemborn et al., 2018b). However, paleosols with defined horizons, peds, and cutans are compatible with relatively more developed soils (e.g., Retallack, 2001) that probably could be interpreted as Alfisol-like paleosols. The studied paleosol types refer to very short-to-short-moderate pedogenesis, and probably they involved tens, hundreds to more than thousand years of soil formation (e.g., Retallack et al., 2000; Retallack, 2001). Consequently, pauses in sedimentation/erosion or stability of the landscape that allowed pedogenesis in FA1 of the SCF were relatively short (101$10^{3} \mathrm{yr}$ ). The very low/low to moderate degree of paleosol development under the warm-temperate and seasonally humid-to-subhumid environment that prevailed during the Early-Middle Miocene in southern Patagonia (Kay et al., 2012; Raigemborn et al., 2018a,b) is likely the consequence of elevated aggradation rates.

\section{FA2- Sheet flood - crevasse splay deposits}

Description. FA2 is composed of centimeter-thick tabular beds of yellowish gray (5Y 8/1) to pale yellowish brown 
(10YR 6/2) fine to medium sandstones. Also, up to 1 meter thick, light colored (N9 and N8) tuffaceous horizons show a fining upward trend are present in low proportion (Fig. 3.1). These beds form a distinctive feature of the SCF in the region. They are usually structureless (facies Sm; Tm) although occasionally they show parallel lamination (facies Sh) or ripple lamination (facies Sr), and show sharp bases and gradational tops to fine-grained beds of FA1, producing finning upward successions at the bed-scale. In minor proportion, some small lenticular bodies with planar base and convex tops were observed (Fig. 3.2), showing internal tractive sedimentary structures such as plane-parallel laminations (facies Sh) or small scale cross-bedding (facies St).

At Barrancas Blancas (EAG2), this facies association hosts an extensive burrow system conforming horizontal and vertical networks (Fig. 4.1-3). The individual branches are subcircular in cross section $(2-3 \mathrm{~cm}$ in diameter) and are passively filled by the overlaying sandstones. The network is composed by burrows of horizontal disposition interconnected to vertical elements. Upward Y-branching and Tbranching are commonly recorded (Fig. 4.5). The burrow lining is usually obscured by an external halo conformed by the host rock (Fig. 4.4), even though when visible, are smooth and structureless.

Interpretation. The dominance of relatively thin tabular sandstone deposits suggest accumulation by tractive currents produced by unconfined flows on the floodplain. These flows are interpreted as the result of fluvial flooding episodes when the flow overtopped the channel levees (Burns et al., 2017). In some cases, the repetitive alternation of muddy and sandy tabular layers suggests accumulation confined within levees. Although occasionally observed in our survey, excepting for the Yaten Huageno locality (Fig. 3), lobe-shaped sandy beds are interpreted as crevasse-
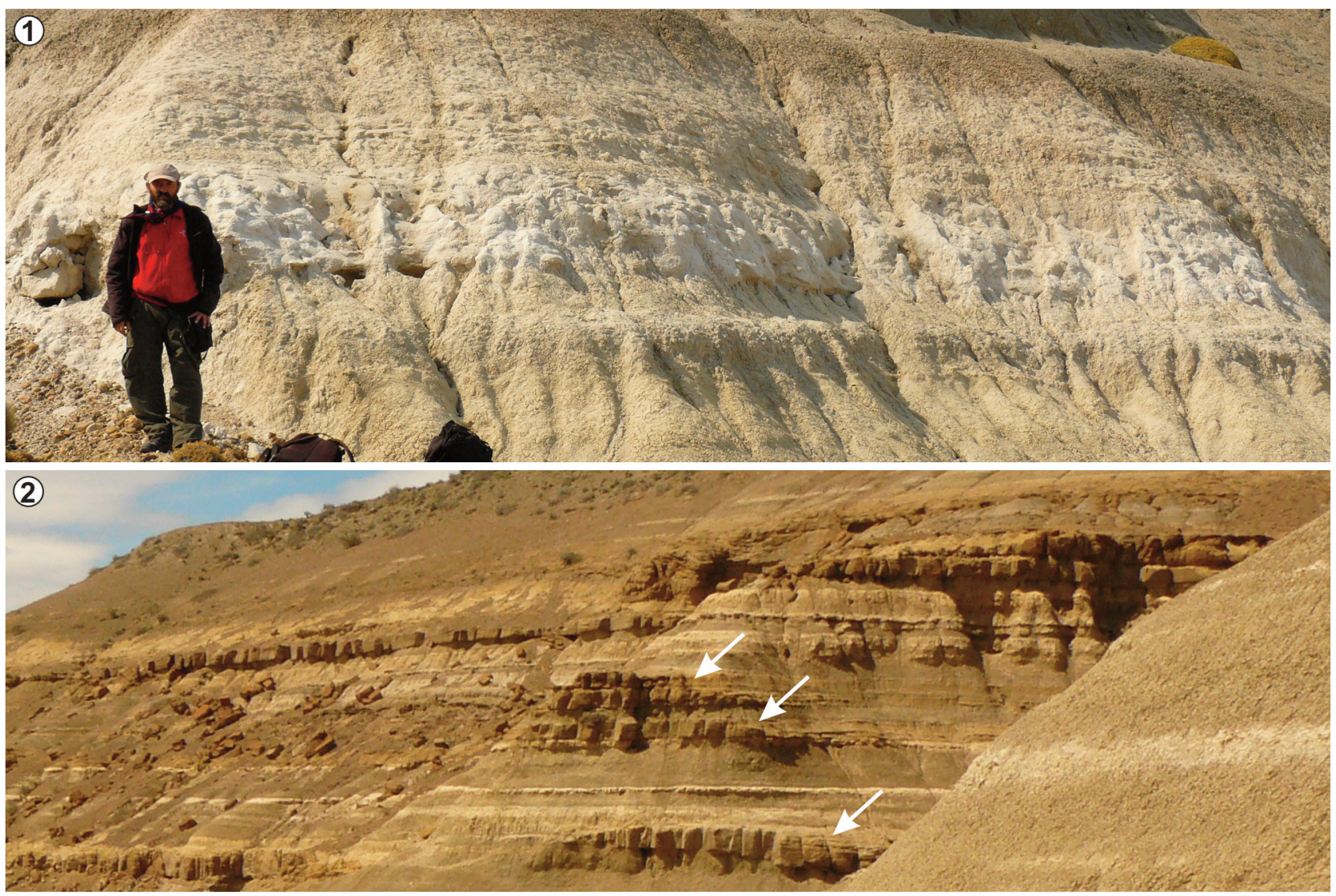

Figure 3. Outcrop views of different features assigned to Facies Association 2. 1, A 1 m-thick, tabular whitish tuff horizon showing fining upward trend, interpreted as a sheet flow deposit. 2, Succession with abundant convex sandstone bodies (arrows), interpreted as lobes formed during crevasse splay events intercalated with floodplain deposits of FA1. 
(1)
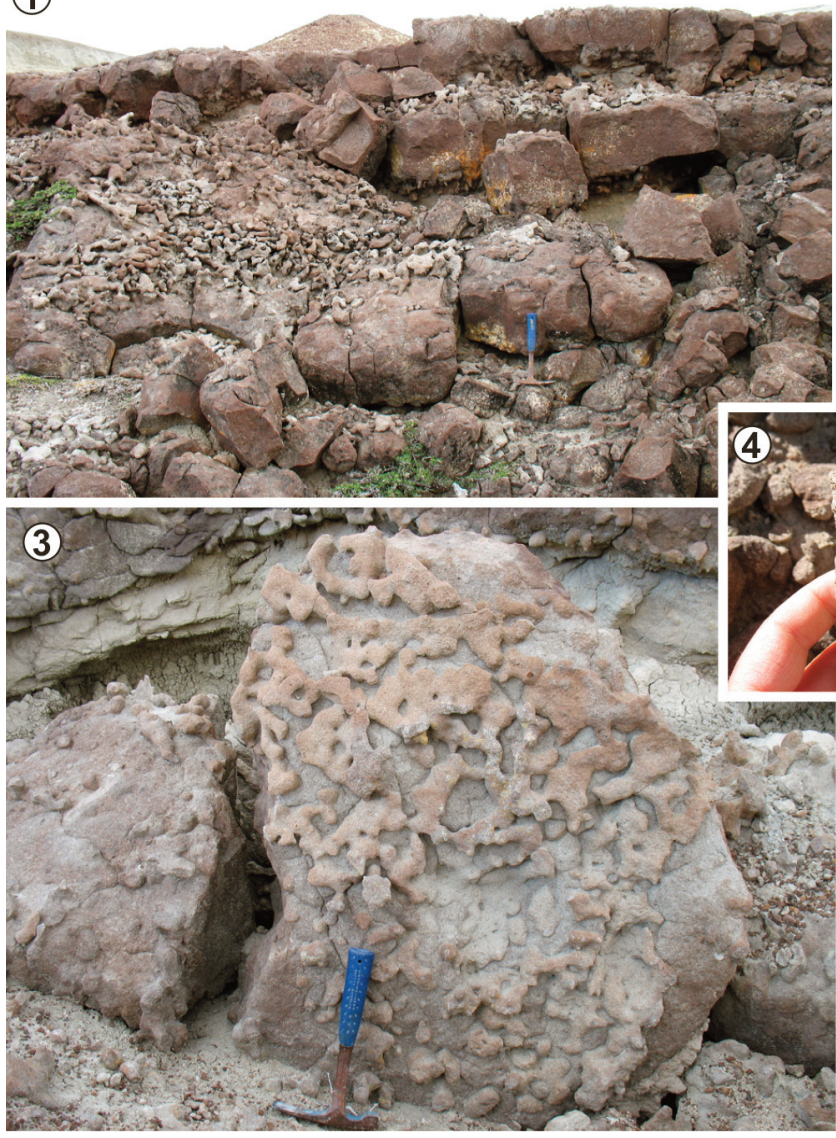

(2)
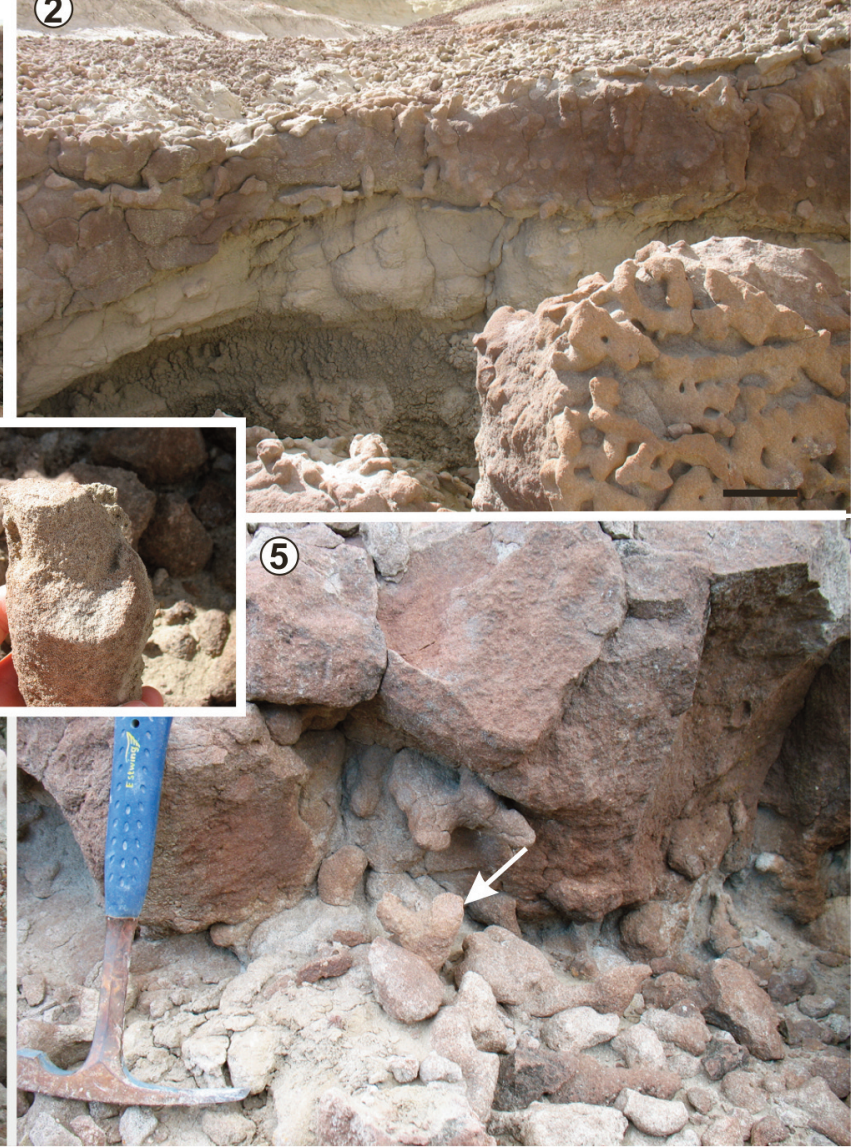

Figure 4. Burrow system described for Facies Association 2. 1-2, General view of the burrow system and the host medium sandstones. Scale bar in $2=10 \mathrm{~cm}$. 3, Detail of the burrows system of horizontal disposition interconnected to vertical elements. 4, Burrow lining obscured by an external layer. 5, Detail of an upward Y-branching burrow (indicated by arrow).

splay deposits. These types of sedimentary bodies are a common element in other SCF localities (Zapata, 2018; Cuitiño et al., 2019). The lack of primary sedimentary structures in the m-thick, tabular tuff beds makes their interpretation difficult. Some cm-thick tuff layers can be interpreted as primary ash fall deposits. However, considering the distance from the Andes, thin-to-thick tuffs are interpreted as the product of reworking of primary volcanic ash fall deposits either by unconfined flows on the floodplains, aeolian processes, or a combination of both. The occurrence of rhizoliths restricted to the upper part of these tuff beds suggests fast accumulation of the tuffaceous material followed by stable conditions and pedogenic modification.

The architecture of the described burrow systems shows a close morphological resemblance to other burrow systems produced by terrestrial and marginal marine deca- pod, such as Camborygma Hasiotis and Mitchell, 1993, Lunulichnus Zonneveld et al., 2006, Loloichnus Bedatou et al., 2008 and Psilonichnus Fürsich, 1981. They differ from the first three mentioned in this list in lacking vertically dominated structure and differs from Psilonichnus by the absence of branches with J and U shape (Fürsich, 1981; Frey et al., 1984; Hasiotis and Mitchell, 1993; Zonneveld et al., 2006; Bedatou et al., 2008). For this reason and until we are able to gather more diagnostic information, we prefer to leave the burrow network without any formal nomenclature.

\section{FA3- Fluvial channel deposits}

Description. FA3 is composed essentially by lenticular sandstone deposits with a sharp, concave base and planar top (Fig. 5.1), sometimes grading upwards to fine-grained deposits of FA1 or FA2. Grain sizes vary between fine and 
coarse sandstone, with subordinate fine gravels. Color ranges from dark gray, grayish yellow $(5 Y 8 / 4)$ to yellowish gray $(5 Y 7 / 2)$. Primary sedimentary structures such as pla- nar and trough cross bedding (facies Sp and St, respectively), as well as plane parallel lamination (facies Sh) are common, forming sets that vary between 0.2 and $1.5 \mathrm{~m}$
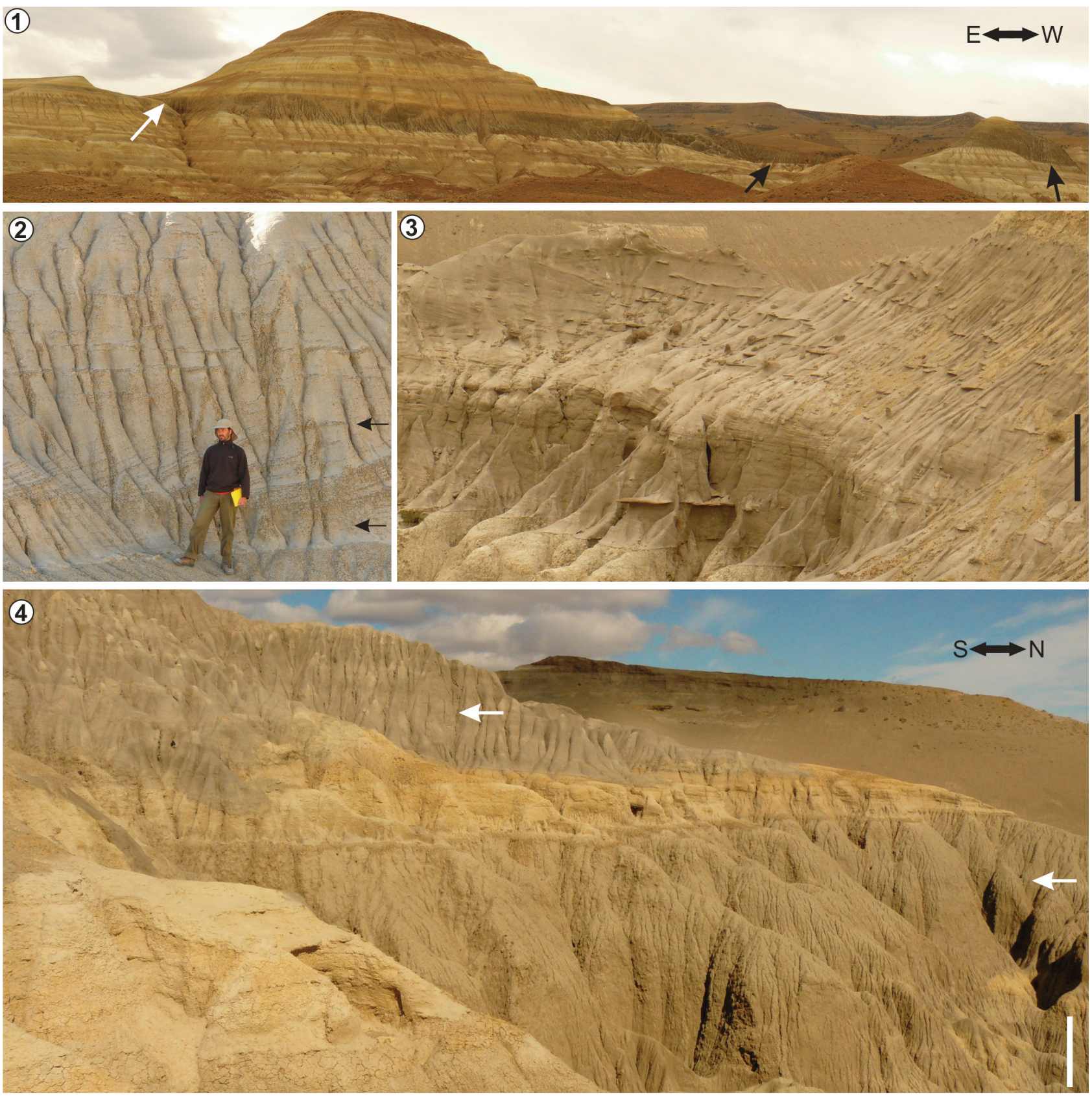

Figure 5. Field photographs of channel deposits of Facies Association 3. 1, Lenticular dark gray sandstone body with irregular, concave base and planar top. The white arrow points to the lateral pinch-out of the body, whereas the black arrows point to the irregular bottom surface close to the thalweg of the channel. The visible lateral extension of this channel is about $150 \mathrm{~m}$. 2, Large-scale cross-bedded set (between arrows; $1.1 \mathrm{~m}$ ) at the base of a thick channel deposit. Upward the sets are no thicker than $0.3 \mathrm{~m}$. 3, Gray sandstone with trough cross stratification in sets of about $0.5 \mathrm{~m}$ thick. Scale bar=1 m. 4, Two thick channel gray sandstones showing organ pipe weathering (white arrows). Primary sedimentary structures are hardly observed in these bodies, although some relict stratification can be observed for the upper one. Scale bar $=1 \mathrm{~m}$. 
thick (Fig. 5.2 and 5.3). The thicker cross-bedded sets are usually observed at the base of these bodies (Fig. 5.2). Due to the poor lithification, many bodies show "organ pipe" weathering patterns without visible structure (Fig. 5.4). Thickness of individual bodies varies between 1 and $7.5 \mathrm{~m}$, whereas apparent width reaches up to $300 \mathrm{~m}$. Some caution on this measurement must be taken because of the limited lateral extension of the exposures and the common lack of paleocurrent indicators useful to locate the crosscurrent orientation of the bodies. Few paleocurrent measurements from cross bedding show $\mathrm{E}$ and NE directions.

Interpretation. Lenticular bodies with erosive bases, infilled with cross bedded sandstones and showing fining upward trends, are interpreted as produced by confined flows typical of fluvial channels (Miall, 2014). They are interbedded within fine-grained deposits of FA1 and FA2. Given the simple infill of the channels and the general reduced thickness of individual bodies, most are interpreted as shallow, single story channels. The lack of evidence for lateral accretion suggests these were fixed channels in a low sinuosity fluvial system (Miall, 2014). In accordance to our interpretation, for the coastal cliff exposures of the SCF, Zapata (2018) also concluded that the most common type of channel for the SCF is the confined, single story channel.

\section{STRATIGRAPHY AND SPATIAL FACIES TRENDS}

The SCF along the southern margin of the Río Santa Cruz valley is exposed in a series of isolated small hills and cliffs located near the valley bottom (Fig. 1.2-3). These were exposed by the erosion of ephemeral streams that transect the valley margin or by the cut bank of the Río Santa Cruz. Most of the area is covered by Miocene-Quaternary terrace fluvial conglomerates or recent alluvial deposits (Fig. 1.23). For these reasons, plus the large distances between the exposures (tens of kilometers), a field-based physical correlation scheme based on guide levels at the regional scale was not feasible.

The SCF strata are subhorizontal, with local dips no higher than $3^{\circ}$ and few normal faults with no more than 10 $\mathrm{m}$ of throw. The maximum measured thickness for the SCF in the study area is $167 \mathrm{~m}$ corresponding to Segundas Barrancas Blancas; $142 \mathrm{~m}$ and $80 \mathrm{~m}$ were measured for Barrancas Blancas and Yaten Huageno, respectively.

The base of the SCF, defined as just above the uppermost oyster shell bed recognized in the underlying marine deposits is only visible in Barrancas Blancas, where one can observe the transition with the underlying Monte Observación Member of the Monte León Formation (Parras and Cuitiño, 2018). For the remaining localities, the base of the unit is covered.

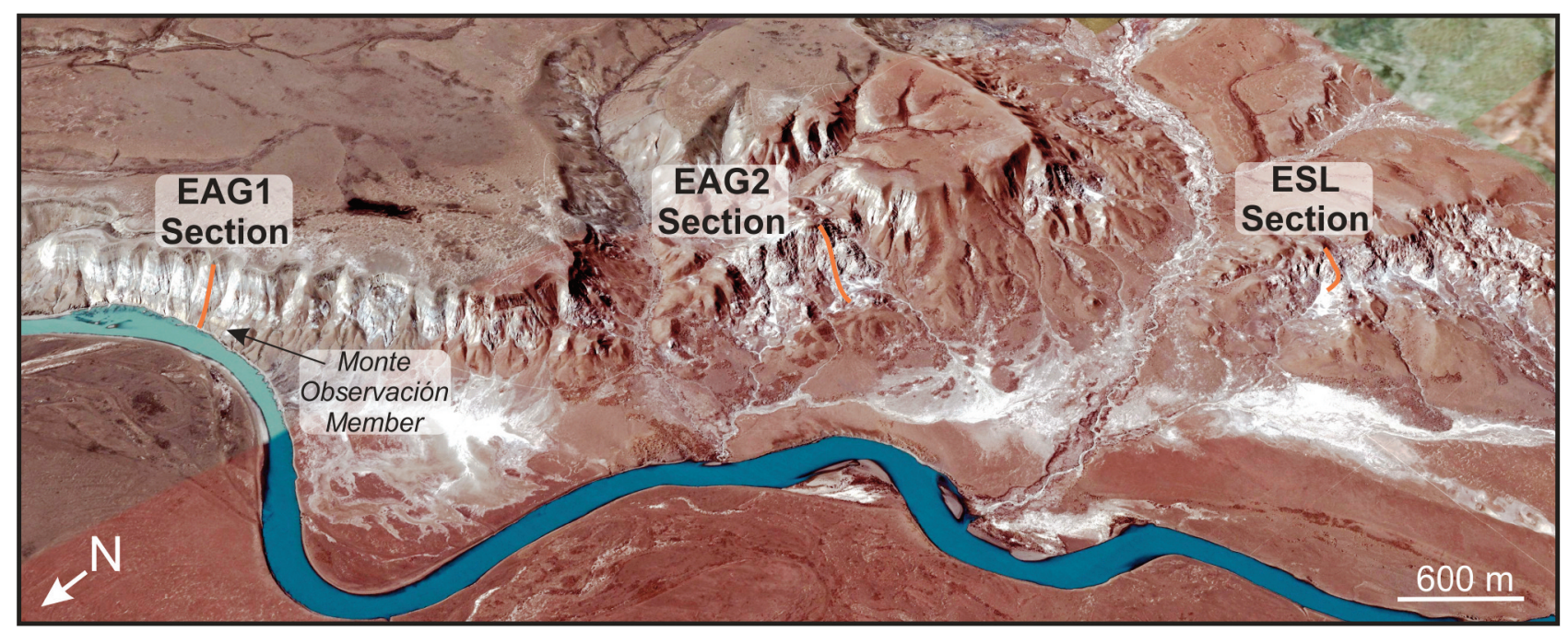

Figure 6. Oblique satellite image (Google Earth TM; 2002) of the Barrancas Blancas locality showing the position of the three measured sections just south of the Río Santa Cruz. In the lower part of the EAG1 Section the brownish strata of the Monte Observación Member of the Monte León Formation is highlighted. 
Several small outcrops of poor quality record the SCF in higher topographic elevations, up to few meters below the uppermost conglomerate of the Terrace II of Pampa de Monte León (Sacomani and Panza, 2011; Cobos et al., 2014) (e.g., Estancia Santa Lucía, Estancia Rincón Grande; Fig. 1.3), which is estimated to be no more than $10 \mathrm{~m}$ thick. Thus, we estimate the thickness of the SCF including covered intervals is about $267 \mathrm{~m}$ for Barrancas Blancas, at least $288 \mathrm{~m}$ for Segundas Barrancas Blancas and at least $380 \mathrm{~m}$ for
Yaten Huageno. This westward increase in thickness is consistent with regional trends observed elsewhere for the SCF in southern of the Province of Santa Cruz (Cuitiño et al., 2016).

Considering only the measured thicknesses of the wellexposed stratigraphic intervals studied here, together with the available ages and using a sedimentation rate of 150 m/Ma (Cuitiño et al., 2016), the estimated time span for the SCF in the studied localities is 17.21-16.3 Ma (Burdigalian)
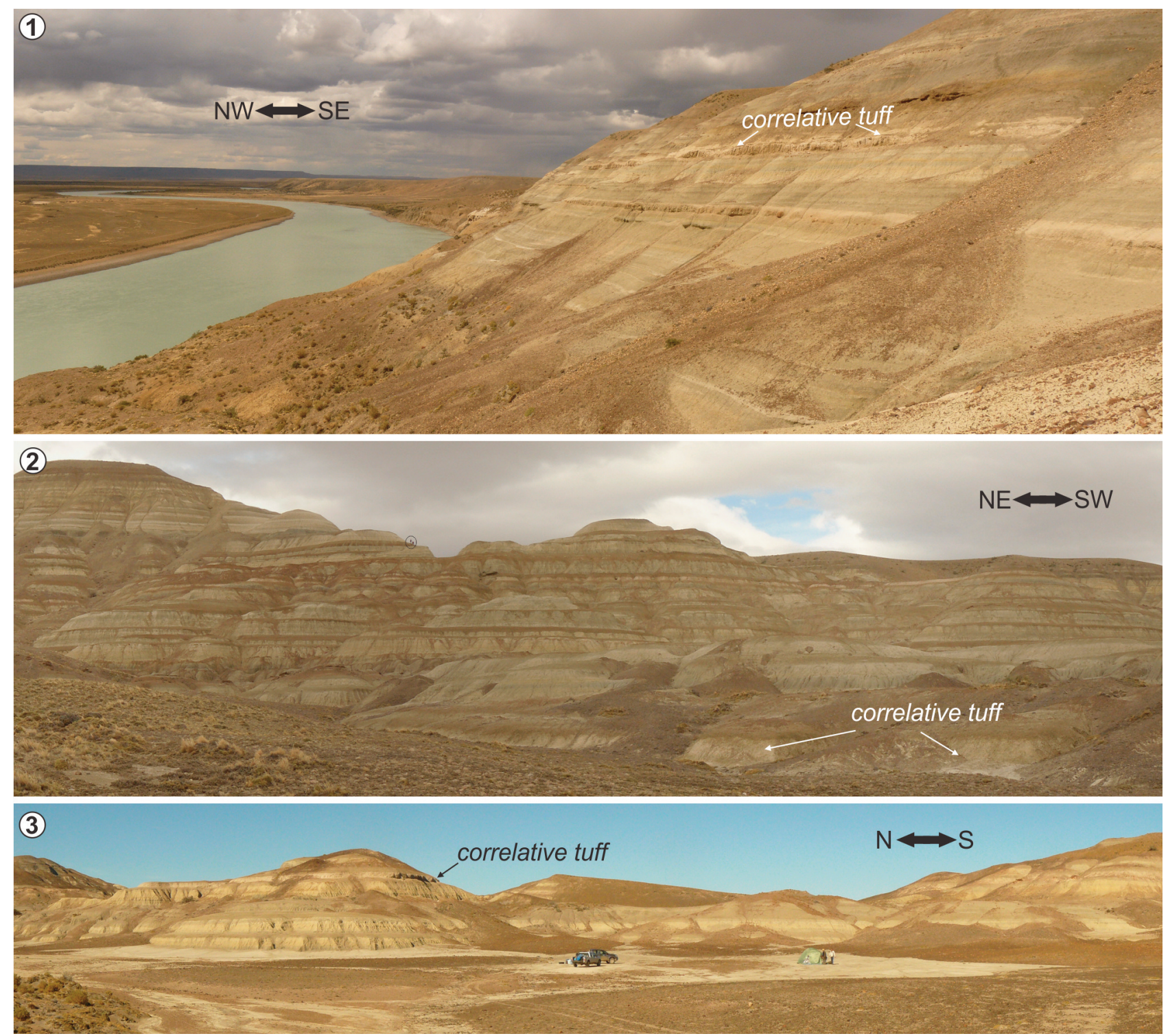

Figure 7. Field panoramic photographs of the three exposures from which sections were measured. 1, Section EAG1 with the correlative tuff highlighted. 2, A thick exposure from Section EAG2. The same correlative tuff of Section EAG1 is highlighted. 3, The small exposure of Section ESL and its correlative tuff. Photographs 1 and 2 taken in December 2012; photograph 3 taken in February 2014. 
200

190

180

Barrancas Blancas

160

150

\section{Section EAG1}

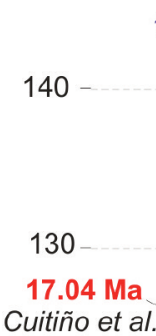

$$
\text { (2016) }
$$

120

110

16.9
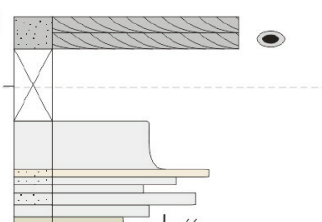

.
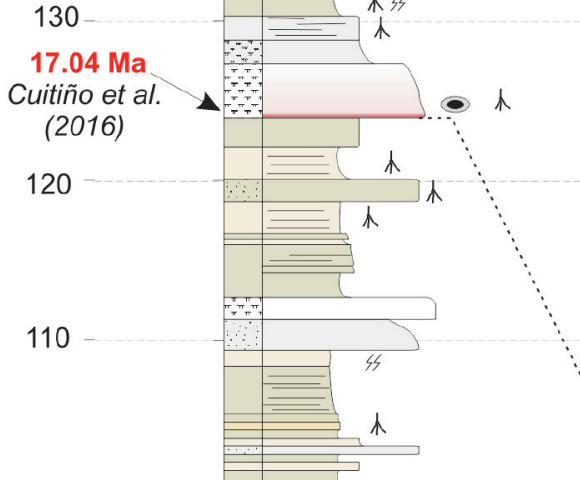

100

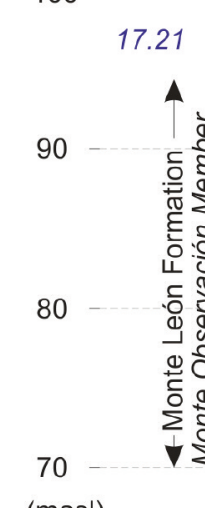

(masl)

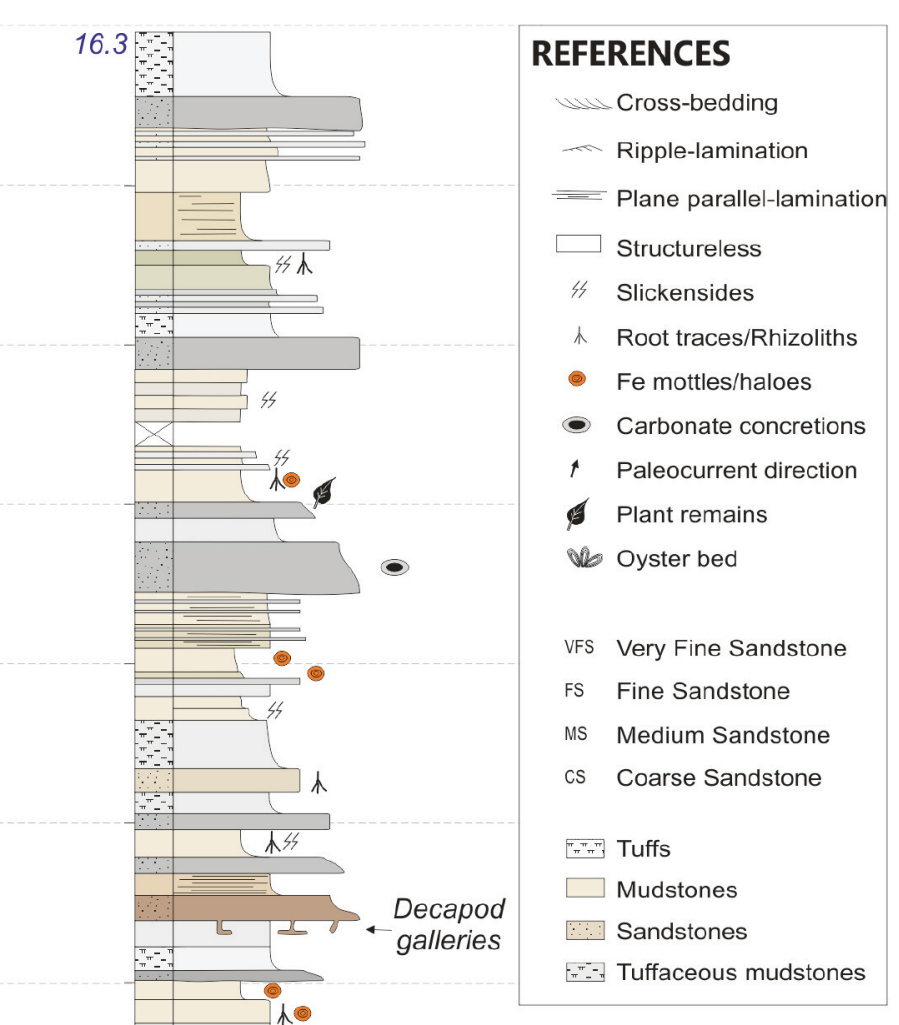

\section{Section ESL}

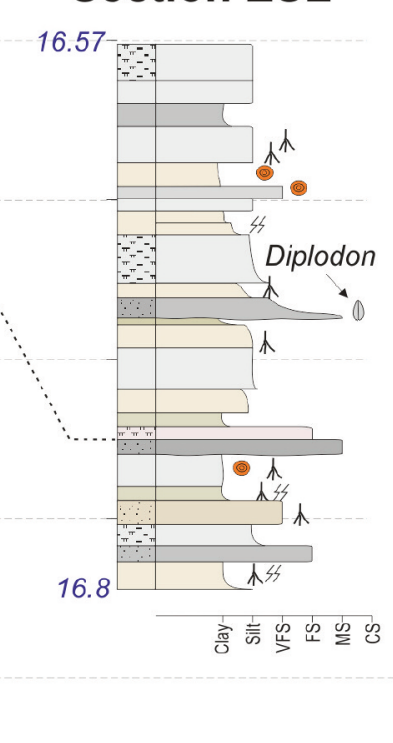

\section{Section EAG2}

Figure 8. Sedimentary sections measured in Barrancas Blancas locality, showing local correlative horizons. The red number indicates the position of the U-Pb age (Cuitiño et al., 2016) whereas the blue numbers are ages estimated upon sedimentation rates. 
for Barrancas Blancas; 16.47-15.3 Ma (Burdigalian-early Langhian) for Segundas Barrancas Blancas; and 17.2116.68 Ma (Burdigalian) for Yaten Huageno. In addition, it is noted that if the isolated high elevation exposures of the SCF Iying just below the Terrace II of Pampa de Monte León conglomerates (see above) are considered in this analysis, the age of the SCF in the Río Santa Cruz should be extended somewhat younger than estimated here and certainly it should comprise part of the Langhian stage.

\section{Barrancas Blancas}

This is the easternmost locality of the study area (Fig. 1) and corresponds to a belt of exposures oriented NE-SW in which we measured three sections: Estancia Aguada Grande 1 (EAG1), Estancia Aguada Grande 2 (EAG2) and Estancia Santa Lucía (ESL) (Figs. 6, 7, 8).

Section EAG1 (S 50 09' 47.6"; W 69 41' 02.2") begins at the Río Santa Cruz level (Fig. 7.1), and is the only one in the study area where the underlying shallow marine to transitional deposits of the Monte Observación Member of the Monte León Formation can be observed (Figs. 6 and 8). Following the criteria of Parras and Cuitiño (2018) the boundary of this member with the overlying SCF is arbitrarily located in the uppermost Crassostrea orbignyi Ihering,
1897 shell bed. Above this contact is a $50 \mathrm{~m}$ thick succession of the lower beds of the SCF composed of deposits assigned mostly to FA1 and FA2, with a conspicuous $3 \mathrm{~m}$ thick tuff bed located $30 \mathrm{~m}$ above the base of the unit (Figs. 7.1 and 8 ). This tuff was dated in $17.04 \pm 0.55$ by means of U/Pb on zircons (Cuitiño et al., 2016), and it is used as a marker bed to correlate with Section EAG2 (Fig. 8). In this part of the SCF no terrestrial fossil vertebrates were recovered.

Section EAG2 is $4 \mathrm{~km}$ southwest of EAG1 (Fig. 6), it is the thickest and most extensive exposure within Barrancas Blancas (Figs. 7.2 and 8). It is the site of a significant vertebrate fossils collection (Fernicola et al., 2019b) and contains a horizon rich in decapod burrows (Fig. 8). It is mostly composed of floodplain deposits of FAs 1 and 2 .

Finally, the ESL Section is a small exposure located $3 \mathrm{~km}$ southwest of EAG2 (Figs. 6 and 7.3). The correlation of this section with EAG2 is performed using a local tuff layer (Fig. 8). In this locality, besides the fossil vertebrate collection (Fernicola et al., 2019b), a level bearing the freshwater bivalve Diplodon sp. was found (Pérez et al., 2019).

\section{Segundas Barrancas Blancas}

This is a belt of $9 \mathrm{~km}$ of exposures composed of several isolated outcrops that lie close to the Río Santa Cruz in Es-

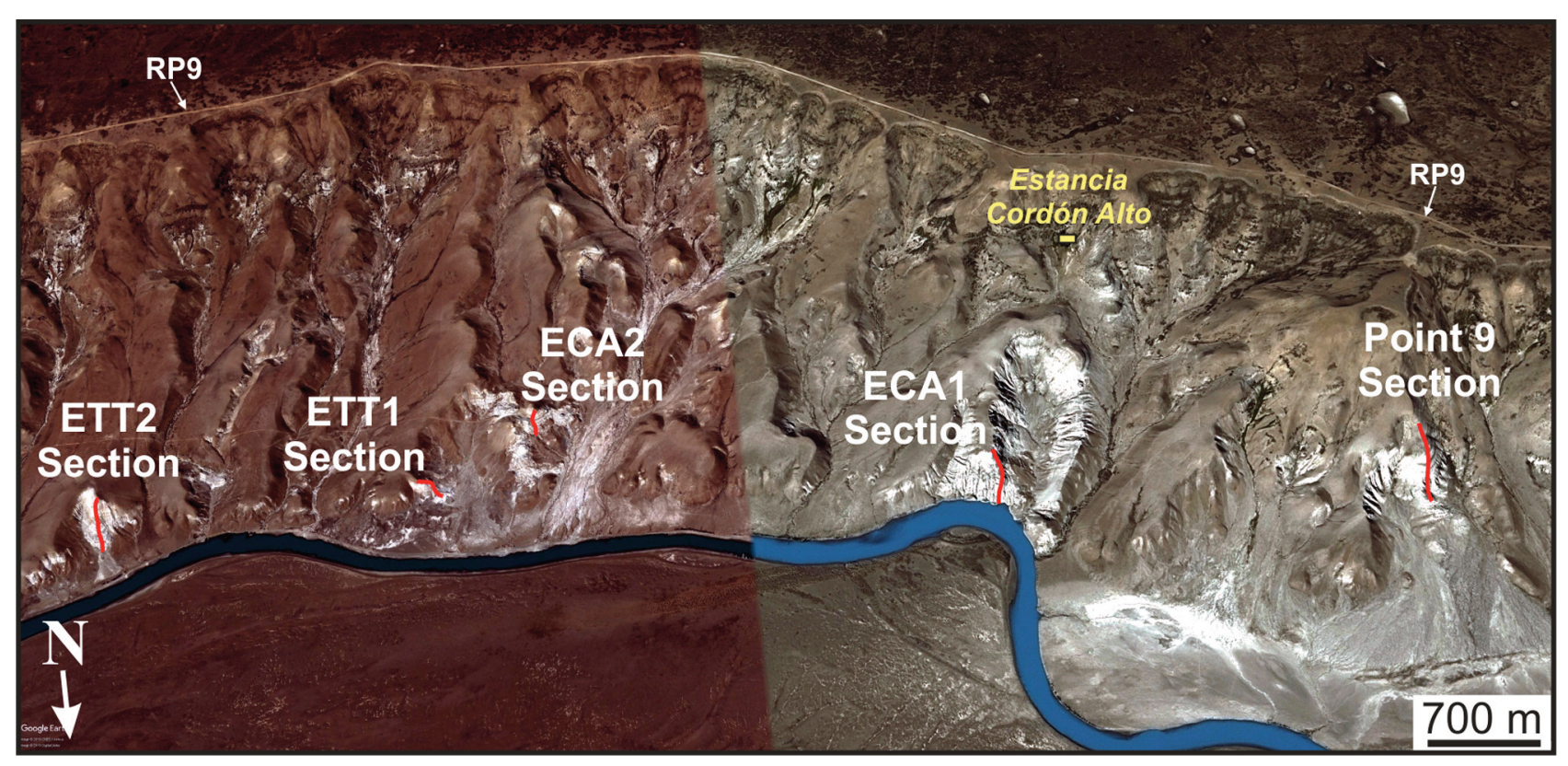

Figure 9. Oblique satellite image of Segundas Barrancas Blancas (from Google Earth TM; 2001), showing the position of the five measured sections. 

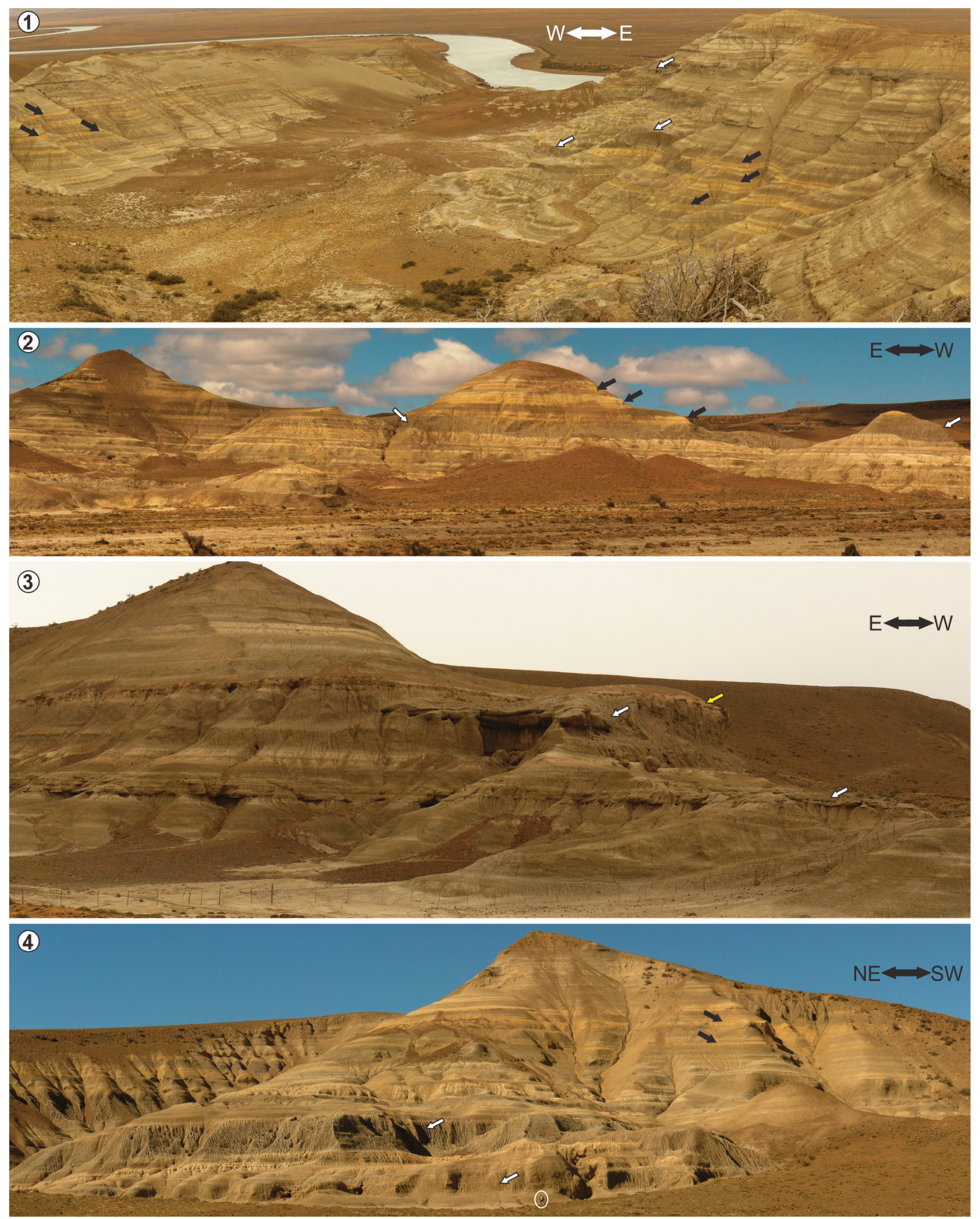

Figure 10. Panoramic photographs of Segundas Barrancas Blancas most representative exposures. In all cases white arrows indicate thick lenticular channel sandstones whereas black arrows point to the yellow beds that were used for correlation. 1, ECA Section viewed from above. 2, ECA2 Section. 3, EET1 Section showing the CECA-2 tuff layer dated by Cuitiño et al. (2016) (yellow arrow). 4, EET2 Section. A person (encircled) as scale. All photographs taken in February 2014. 

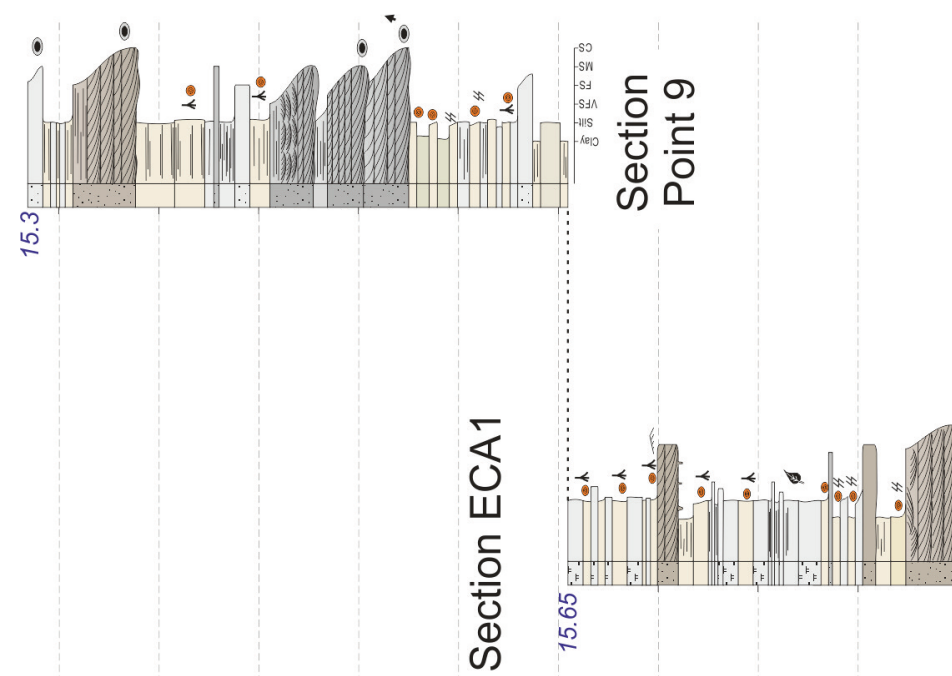

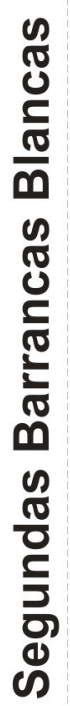
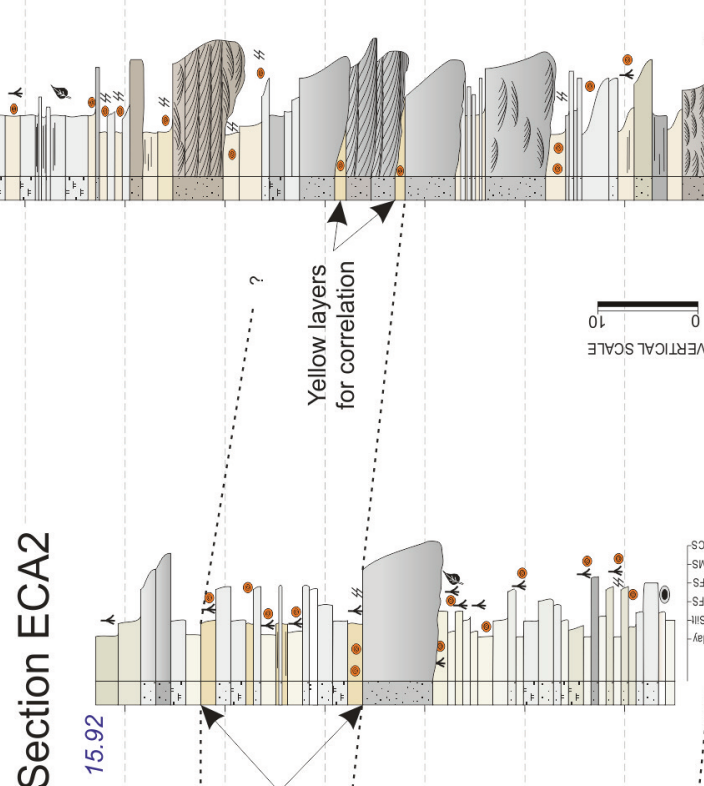

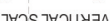

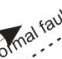


tancia Cordón Alto and Estancia El Tordillo (Figs. 1, 9, and 10). Here we measured five sections (Fig. 11), which from east to west are: Estancia El Tordillo 2 (EET2; S 50 16' 39.08"; W 70 13' 26.18"), Estancia El Tordillo 1 (EET1; S50 16' 43.00"; W 70 15' 9.90"), Estancia Cordón Alto 2 (ECA2; S 50 16' 55.96"; W 70 15' 47.33"), Estancia Cordón Alto 1 (ECA1; S 50 16' 25.56"; W 70 18' 24.74"), and Point 9 (S 50 16' 16.30"; W 70 20' 48.60") (Figs. 9 and 11). In each of these sections vertebrate fossils were recovered (Fernicola et al., 2019b).

The SCF here is composed of fine-grained sediments of FAs 1 and 2, although conspicuous lenticular sandstone bodies of FA3 are observed (Fig. 10). The sections are locally correlated using a tuff layer (CECA-2 tuff; Cuitiño et al., 2016) and tabular, laterally extensive and distinctive yellow beds (Figs. 10 and 11). The CECA-2 tuff layer is about $1 \mathrm{~m}$ thick (Fig. 10.3) and was dated at the EET1 Section by Cuitiño et al. (2016) with an age of $16.32 \pm 0.62 \mathrm{Ma}$. This tuff allows the correlation of Section EET1 with Section ECA1 (Fig. 11) $3.5 \mathrm{~km}$ away. Conspicuous yellow beds also used for correlation are a package of about $10 \mathrm{~m}$ of fine-grained sediments assigned to FA1 that contains two or three layers that contrast in color with the remaining beds of the SCF (Fig. 10). These beds were used to correlate sections EET2, ECA2 and ECA1 (Fig. 11). Although present in Section ECA, the yellow layers are barely visible due to the presence of thick lenticular sandstone deposits that partly erode them (Figs. 10.1 and 11). Finally, due to the lack of guide levels, Section Point 9 was located in the correlation scheme according to its elevation above sea level (Fig. 11).

\section{Yaten Huageno}

This locality has a single section (Fig. 12; S 50 ${ }^{\circ} 1^{\prime}$ 40.74; W 71 ${ }^{\circ} 3^{\prime} 48.81^{\prime \prime}$ ) in which vertebrate fossils were recovered (Fernicola et al., 2019b). Due to the geographic isolation of this section, physical correlation to other sections is nearly impossible to perform. Here, the SCF is composed of a mixture of fine-grained deposits of FA1 and lenticular to tabular sandy deposits of FA2 and FA3 (Figs. 12 and 13). For this section, a tuff layer has been dated in $16.88 \pm 0.65 \mathrm{Ma}$ (Cuitiño et al., 2016).

\section{OVERVIEW AND CONCLUDING REMARKS}

Overall, the SCF in the study area is composed of bioturbated and pedogenized poorly consolidated fine-grained sediments with abundant tuffaceous material, mostly represented by floodplain deposits of FA1 and sheet flood to crevasse splay deposits of FA2. Lenticular, cross-bedded sandstone bodies deposited by fluvial channels of FA3 are a minor component of the unit. Conglomerates are only observed as layers of granule to fine-gravel intercalated within sandstone deposits or forming lags at the base of channel sandstone beds. The vertical proportion of the three FAs here defined remains homogeneous for all the studied sections, suggesting an aggradational stacking pattern for the SCF in this region.

The three studied localities of the SCF could not be physically correlated because of the large distances between them and the absence of regional guide levels. However, based on the available $\mathrm{U}-\mathrm{Pb}$ ages and the estimated sedimentation rates (Cuitiño et al., 2016), they can be

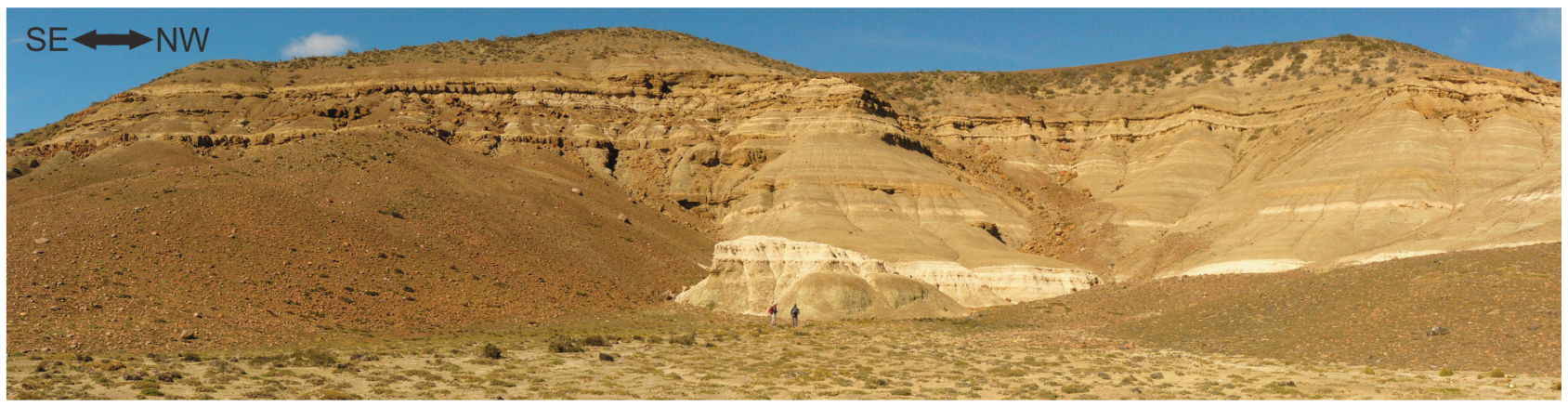

Figure 12. Panoramic photographs of the exposure where the Yaten Huageno section was measured. The whitish strata correspond to tuffs whereas the beds projecting off the exposure are sandstone bodies. Note two persons at the base of the outcrop as scale. Photographs taken in December 2012. 
chronologically correlated, being deposited in a time interval between 17.2 and 15.3 Ma (Burdigalian-early Langhian).

Paleocurrent data is scarce because of the poor preservation of primary sedimentary structures. Some isolated measurements point to N, NE and E paleoflows, but this must be taken with caution since the channel sinuosity was not evaluated. The studied exposures of the SCF are arranged in a west to east trend, i.e., approximately parallel to the paleoflow. This is based on the assumption that the Southern Patagonian Andes were a high topographic feature that produced the drainage network to flow eastward, as presently occurs. This is supported by the paleocurrent data and fluvial channel architecture from the coastal localities that show a main paleoflow to the east (Zapata, 2018). This, together with the synchronicity of the SCF among localities of the Río Santa Cruz, implies that Yaten Huageno represents sedimentation roughly 140 km upstream in relation to Barrancas Blancas. In Yaten Huageno several sandstone channels are composed of coarse-sandstones and some reach up to granule-size deposits (Fig. 13), whereas in Barrancas Blancas the sandstone deposits are mostly composed of fine to medium sandstones, with few thin coarse sandstone levels (Fig. 8). This eastward finning grain size trend observed among the channel sandstones in the studied localities supports the idea of a West to East drainage pattern.

The Decapod burrow system recorded at Barrancas Blancas has a strong horizontal component, differing from what has been described until now for crayfish burrows, dominated by vertically components (e.g., Hasiotis and Mitchells, 1993; Bedatou et al., 2008). On the other hand, land crabs as Gecarcinidae and Coenobitidae (Brachyura) typically produce extensive burrow systems along riverbanks, within several kilometers from the sea, where they leave their marine larvae (Maitland and Maitland, 1985; Vannini et al., 2003). The South American freshwater crab Trichodactylidae (Brachyura) excavate along ditches, river banks or wetlands; while the freshwater crayfish Parastacidae excavates burrows not necessary connected to water courses, mostly in soils where they reach the water table (Genise, 2017). Therefore, even though the Barrancas Blancas burrows were found at the easternmost locality, based on the sedimentological evidence for the corresponding terrestrial horizons, the idea of a coastal-influenced paleoenvironment is discounted: freshwater crabs or crayfish could have produced the Barrancas Blancas burrows.

Paleosols developed in the SCF along the Río Santa Cruz valley are abundant although all show an overall very poor/poor to moderate degree of development, which would be assigned to paleo-Entisols, -Inceptisols, and Alfisol-like paleosols. They occur mostly on fine-grained deposits interpreted as distal floodplain deposits (FA1).

\section{Yaten Huageno}

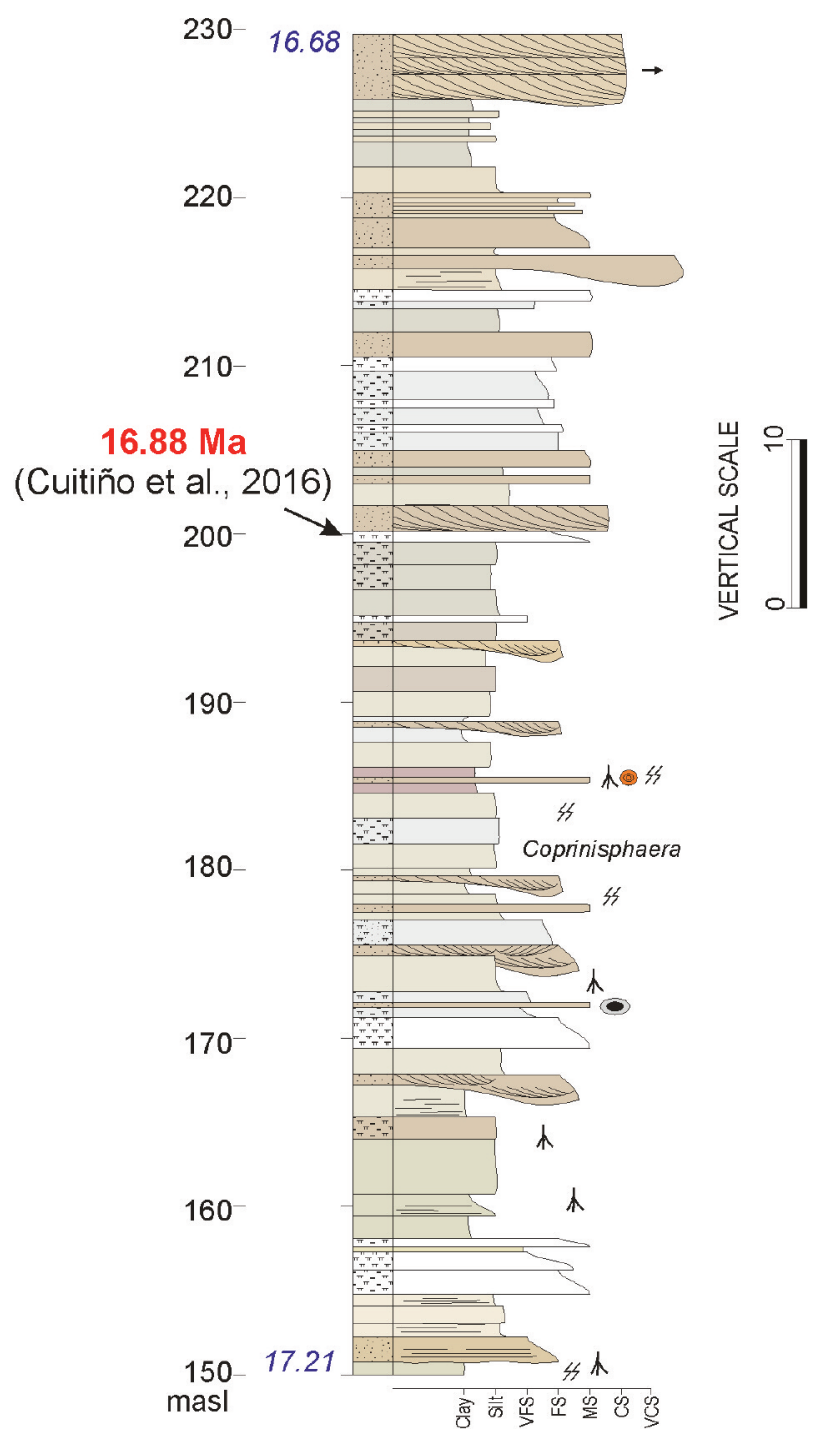

Figure 13. Sedimentary section measured for Yaten Huageno locality showing the dated horizon. The red number indicates the U/Pb age whereas the blue numbers are estimated upon sedimentation rates. For references see Figure 8. 


\section{ACKNOWLEDGMENTS}

We acknowledge the owners and workers of the estancias for providing access to the study sites and logistic support for fieldwork. S. F. Vizcaíno, M. S. Bargo, and R. F. Kay provided logistic and financial support. N. Muñoz is acknowledged for his valuable help in the field. Finally, we thank two anonymous reviewers and R. F. Kay for their constructive comments and suggestions on the original version of this manuscript. This is a contribution to projects PIP-CONICET 00781, UNLP 11/N867, CBLUJ 0000030-18, PICT 2013-0389 and 2017-1081, National Science Foundation grants 0851272 and 1348259, and National Geographic Society grant 9167-12.

\section{REFERENCES}

Aramendía, I., Cuitiño, J.I., Ghiglione, M.C., and Bouza, P.J. in press. Tectonostratigraphic significance of the Neogene sedimentary record of northwestern Austral-Magallanes Basin, Argentinean Patagonia. Latin American Journal of Sedimentology and Basin Analysis 26.

Ashley, G.M., and Driese, S.G. 2000. Paleopedology and paleohydrology of a volcaniclastic paleosol interval: implications for early Pleistocene stratigraphy and paleoclimate record, Olduvai Gorge, Tanzania. Journal of Sedimentary Research 70: 10651080.

Bargo, M.S., Cerdeño, E., Olivero, E.B., López Cabrera, M.I., Reguero, M.A., and Vizcaíno, S.F. 2018. Primer registro de Astrapotheriidae (Mammalia, Astrapotheria) de la Formación Cullen (Mioceno temprano) de Tierra del Fuego. Publicación Electrónica de la Asociación Paleontológica Argentina, Suplemento de resúmenes 19: R35.

Bedatou, E., Melchor, R.N., Bellosi, E., and Genise, J.F. 2008. Crayfish burrows from Late Jurassic-Late Cretaceous continental deposits of Patagonia: Argentina. Their palaeoecological, palaeoclimatic and palaeobiogeographical significance. Palaeogeography, Palaeoclimatology, Palaeoecology 257: 169-184.

Biddle, K.T., Uliana, M.A., Mitchum, R.M., Fitzgerald, M.G., and Wright, R.C. 1986. The stratigraphy and structural evolution of the central and eastern Magallanes Basin, southern South America. In: P.A. Allen, and P. Homewood (Eds.), Foreland Basins. International Association of Sedimentologists, Special Publication 8: 41-61.

Bown, T.M., and Fleagle, J.G. 1993. Systematics, biostratigraphy, and dental evolution of the Palaeothentidae, later Oligocene to early-middle Miocene (Deseadan-Santacrucian) caenolestoid marsupials of South America. Journal of Paleontology 67: 1-76.

Buol, W.S., Southard, R.J., Graham, R.C., and McDanield, P.A. 2011. Soil Genesis and Classifications. Sixth edition, Wiley-Blackwell, Oxford, $543 \mathrm{p}$.

Burns, C.E., Mountney, N.P., Hodgson, D.M., and Colombera, L. 2017. Anatomy and dimensions of fluvial crevasse-splay deposits: Examples from the Cretaceous Castlegate Sandstone and Neslen Formation, Utah, USA. Sedimentary Geology 351: 21-35.

Catena, A.M., Hembree, D.I., Saylor, B.Z., Anaya, F., and Croft, D.A. 2016. Paleoenvironmental analysis of the Neotropical fossil mammal site of Cerdas, Bolivia (middle Miocene) based on ichnofossils and paleopedology. Palaeogeography, Palaeoclimatology, Palaeoecology 459: 423-439.

Cobos, J.C., Rodríguez, M.F., and Panza, J.L. 2014. Hoja Geológica 5172-II, Paso Río Bote, Provincia de Santa Cruz. Instituto de Geología y Recursos Minerales, Boletín del Servicio Geológico Minero Argentino 405: 1-99.

Cuitiño, J.I., Fernicola, J.C., Kohn, M.J., Trayler, R., Naipauer, M., Bargo,
M.S., Kay, R.F., and Vizcaíno, S.F. 2016. U-Pb geochronology of the Santa Cruz Formation (early Miocene) at the Río Bote and Río Santa Cruz (southernmost Patagonia, Argentina): Implications for the correlation of fossil vertebrate localities. Journal of South American Earth Sciences 70: 198-210.

Cuitiño, J.I., and Scasso, R.A. 2010. Sedimentología y paleoambientes del Patagoniano y su transición a la Formación Santa Cruz al sur del Lago Argentino, Patagonia Austral. Revista de la Asociación Geológica Argentina 66: 406-417.

Cuitiño, J.I., Vizcaíno, S.F., Bargo, M.S., and Aramendía, I. 2019. Sedimentology and fossil vertebrates of the Santa Cruz Formation (early Miocene) in Lago Posadas, southwestern Patagonia, Argentina. Andean Geology 46: 383-420.

Encinas, A., Folguera, A., Riffo, R., Molina, P., Paz, L.F., Litvak, V.D., Colwyn, D.A., Valencia, V.A., and Carrasco, M. 2019. Cenozoic basin evolution of the Central Patagonian Andes: Evidence from geochronology, stratigraphy, and geochemistry. Geoscience Frontiers 10: 1139-1165.

Fernicola, J.C., Bargo, M.S., Vizcaíno, S.F., and Kay, R.F. 2019a. Historical background for a revision of the paleontology of the Santa Cruz Formation (Early-Middle Miocene) along the Río Santa Cruz, Patagonia, Argentina. In: J.C. Fernicola, M.S. Bargo, S.F. Vizcaíno, and R.F. Kay (Eds.), Early-Middle Miocene Paleontology in the Rio Santa Cruz, Southern Patagonia, Argentina. 130 years since Ameghino, 1887. Publicación Electrónica de la Asociación Paleontológica Argentina 19: 1-13.

Fernicola, J.C. Vizcaíno, S.F., Bargo, M.S., Kay. R.F., and Cuitiño, J.I. 2019b. Analysis of the Early-Middle Miocene mammal associations at the Río Santa Cruz (Patagonia, Argentinba). In: J.C. Fernicola, M.S. Bargo, S.F. Vizcaíno, and R.F. Kay (Eds.), EarlyMiddle Miocene Paleontology in the Río Santa Cruz, Southern Patagonia, Argentina. 130 years since Ameghino, 1887. Publicación Electrónica de la Asociación Paleontológica Argentina 19: 239-259.

Fernicola, J.C., Cuitiño, J.I., Vizcaíno, S.F., Bargo, M.S., and Kay, R.F. 2014. Fossil localities of the Santa Cruz Formation (early Miocene, Patagonia, Argentina) prospected by Carlos Ameghino in 1887 revisited and the location of the Notohippidian. Journal of South American Earth Sciences 52: 94-107.

Fosdick, J.C., Grove, M., Hourigan, J.K., and Calderón, M. 2013. Retroarc deformation and exhumation near the end of the Andes, southern Patagonia. Earth and Planetary Science Letters 361: 504-517.

Frey, R.W., Curran, H.A., and Pemberton, S.G. 1984. Tracemaking activities of crabs and their environmental significance: the ichnogenus Psilonichnus. Journal of Paleontology 58: 333-350.

Fürsich, F.T. 1981. Invertebrate trace fossils from the Upper Jurassic of Portugal. Comunicações dos Serviços Geológicos de Portugal 67: $153-168$.

Genise, J.F. 2017. Ichnoentomology: insect traces in soils and paleosols. Topics in Geobiology 37, Springer International Publishing, Switzerland, $695 \mathrm{p}$.

Ghiglione, M.C., Ramos, V.A., Cuitiño, J.I., and Varberón, V. 2016. Growth of the Southern Patagonian Andes (46-53 $\left.{ }^{\circ} \mathrm{S}\right)$ and their Relation to Subduction Processes. In: A. Folguera, M. Naipauer, L. Sagripanti, M. Ghiglione, D. Orts, and L. Giambiagi (Eds.), Growth of the Southern Andes. Springer Earth System Sciences, Springer International Publishing, Switzerland, p. 201-240. Doi: 10.1007/978-3-319-23060-3

Hasiotis, S.T., and Mitchell, C.E. 1993. A comparison of crayfish burrows morphologies: Triassic and Holocene fossil, paleo- and neoichnological evidence and identification of their burrowing 
signatures. Ichnos 2: 291-314.

Kay, R.F., Vizcaíno, S.F., and Bargo, M.S. 2012. A review of the paleoenvironment and paleoecology of the Miocene Santa Cruz Formation. In: S.F. Vizcaíno, R.F. Kay, and M.S. Bargo (Eds.), Early Miocene Paleobiology in Patagonia: High-Latitude Paleocommunities of the Santa Cruz Formation. Cambridge University Press, Cambridge, p. 331-365.

Krapovickas, V. 2012. Ichnology of distal overbank deposits of the Santa Cruz Formation (late Early Miocene): paleohydrologic and paleodimatic significance. In: S.F. Vizcaíno, R.F. Kay, and M.S. Bargo (Eds.), Early Miocene Paleobiology in Patagonia: High-Latitude Paleocommunities of the Santa Cruz Formation. Cambridge University Press, Cambridge, p. 91-103.

Kraus, M.J., and Hasiotis, S.T. 2006. Significance of different modes of rhizolith preservation to interpreting paleoenvironmental and paleohydrologic settings: examples from Paleogene paleosols, Bighorn Basin, Wyoming, U.S.A. Journal of Sedimentary Research 76: 633-646.

Maitland, P., and Maitland, D. 1985. The Australian desert crab. Australian Natural History 21: 496-498.

Marshall, L., Hoffstetter, R., and Pascual, R. 1983. Mammals and stratigraphy: geochronology of the continental mammal-bearing Tertiary of South America. Palaeovertebrata, Mémoire Extraordinaire 1984: 1-76.

Matheos, S.D., and Raigemborn, M.S. 2012. Sedimentology and paleoenvironment of the Santa Cruz Formation. In: S.F. Vizcaino, R.F. Kay, and M.S. Bargo (Eds.), Early Miocene Paleobiology in Patagonia: High-Latitude Paleocommunities of the Santa Cruz Formation. Cambridge University Press, Cambridge, p. 59-82.

Miall, A.D. 2014. Fluvial Depositional Systems. Springer, Switzerland, $316 \mathrm{p}$.

Olivero, E., López, C.M.I., and Reguero, M. 2015. Icnología de los depósitos fluviales de la Formación Cullen (Mioceno, Tierra del Fuego) y su relación con la Formación Santa Cruz (Mioceno) de Patagonia. $3^{\circ}$ Simposio Latinoamericano de Icnología (Colonia del Sacramento), p. 60.

Parras, A.M., and Cuitiño, J.I., 2018. The stratigraphic and paleoenvironmental significance of the regressive Monte Observación Member, early Miocene of the Austral Basin, Patagonia. Latin American Journal of Sedimentology and Basin Analysis 25: 25-47.

Pascual, R., Ortega Hinojosa, E.J., Gondar, D., and Tonni, E.P. 1965. Las edades del Cenozoico mamalífero de la Argentina, con especial atención a aquéllas del territorio bonaerense. Anales de la Comisión de Investigaciones Científicas de la Provincia de Buenos Aires 6: 165-193.

Pérez, L.M., Cuitiño, J.I., Varela, A.N., and Muñoz, N.A. 2019. Diplodon cf. colhuapiensis (Bivalvia, Hyriidae) in the Santa Cruz Formation (Early-Middle Miocene), at the Río Santa Cruz, Patagonia, Argentina. Stratigraphic and paleoenvironmental considerations. In: J.C. Fernicola, M.S. Bargo, S.F Vizcaíno, and R.F. Kay (Eds.), Early-Middle Miocene Paleontology in the Río Santa Cruz, Southern Patagonia, Argentina. 130 years since Ameghino, 1887. Publicación Electrónica de la Asociación Paleontológica Argentina 19: 34-47.

Perkins, M.E., Fleagle, J.G., Heizler, M.T., Nash, B., Bown, T.M., Tauber, A.A., and Dozo, M.T. 2012. Tephrochronology of the Miocene Santa Cruz and Pinturas Formations, Argentina. In: S.F. Vizcaíno, R.F. Kay, and M.S. Bargo (Eds.), Early Miocene Paleobiology in Patagonia: High-Latitude Paleocommunities of the Santa Cruz Formation. Cambridge University Press, Cambridge, p. 23-40.

Raigemborn, M.S., Krapovickas, V., Beilinson, E., Peral, L.e.g., Zucol, A.F., Zapata, L., and Sial, A.N. 2018a. Multiproxy studies of Early
Miocene pedogeniccalcretes in the Santa Cruz Formation of southern Patagonia, Argentina indicate the existence of a temperate warm vegetation adapted to a fluctuating water table. Palaeogeography, Palaeoclimatology, Palaeoecology 500: 1-23.

Raigemborn, M.S., Krapovickas, V., Zucol, A.F., Zapata, L., Beilinson, E., Toledo, N., Perry, J., Lizzoli, S., Martegani, L., Tineo, D., and Passeggi, E. 2018b. Paleosols and related soil-biota of the early Miocene Santa Cruz Formation (Austral-Magallanes Basin, Argentina): a multidisciplinary approach to reconstructing ancient terrestrial landscapes. Latin American Journal of Sedimentology and Basin Analysis 25: 117-148.

Raigemborn, M.S., Matheos, S.D., Krapovickas, V., Vizcaíno, S.F., Bargo, M.S., Kay, R.F., Fernicola, J.C., and Zapata, L. 2015. Paleoenvironmental reconstruction of the coastal Monte León and Santa Cruz formations (Early Miocene) at Rincón del Buque, Southern Patagonia: A revisited locality. Journal of South American Earth Sciences 60: 31-55.

Retallack, G.J. 2001. Soils of the Past. An introduction to paleopedology. 2nd edition, Blackwell Science, Oxford, $404 \mathrm{p}$.

Retallack, G.J., Bestland, E.A., and Fremd, T. 2000. Eocene and Oligocene Paleosols in Central Oregon. Geological Society of America, Special Papers 344. Boulder, $196 \mathrm{p}$.

Sachse, F.V., Strozyk, F., Anka, Z., Rodriguez, J.F., and di Primio, R. 2016. The tectono-stratigraphic evolution of the Austral Basin and adjacent areas against the background of Andean tectonics, southern Argentina, South America. Basin Research 28: 462-482.

Sacomani, L.E., and Panza, J.L. 2011. Hojas Geológicas 5169-I y 5169-II, Puerto Coig y Puerto Santa Cruz, Provincia de Santa Cruz. Instituto de Geología y Recursos Minerales, Boletín del Servicio Geológico Minero Argentino 392: 1-133.

Stoops, G., Marcelino, V., and Mess, F. 2010. Interpretation of Micromorphological Features of Soils and Regoliths. Elsevier, Amsterdam, $752 \mathrm{p}$.

Tauber, A.A. 1999. Los vertebrados de la Formación Santa Cruz (Mioceno inferior-medio) en el extremo sureste de la Patagonia y su significado paleoecológico. Revista Española de Paleontología 14: 173-182.

Tauber, A.A., Palacios, M.E., Krapovickas, J., and Rodríguez, P. 2008. La Formación Santa Cruz (Mioceno temprano-medio) en la mitad occidental del Río Santa Cruz, Patagonia, Argentina. $17^{\circ}$ Congreso Geológico Argentino (San Salvador de Jujuy), Actas: 1500-1501.

Tejedor, M.F., Tauber, A.A., Rosenberger, A.L., Swisher, C.C., and Palacios, M.E. 2006. New primate genus from the Miocene of Argentina. Proceedings of the National Academy of Sciences 103: 5437-5441.

Trayler, R., Schmitz, M., Cuitiño, J.I., Kohn, M., Bargo, M.S., Kay, R., Strömberg, C., and Vizcaíno, S.F. 2019. An Improved Approach to Age-Modeling in Deep Time: Implications for the Santa Cruz Formation, Argentina. Geological Society of America Bulletin. Doi: 10.1130/B35203.1

Ugalde, R., Bostelmann, E., Buldrini, K.E., and Oyarzún, J.L. 2015. Lithofacies, architecture, and depositional environments of the Santa Cruz Formation in Chilean Patagonia. $14^{\circ}$ Congreso Geológico Chileno (La Serena), p. 816-820.

Vannini, M., Cannicci, S., Berti, R., and Innocenti, G. 2003. Cardisoma carnifex (Brachyura): where have all the babies gone? Journal of Crustacean Biology 23: 55-59.

Vizcaíno, S.F., Bargo, M.S., Cuitiño, J.I., Pérez, M.E., Muñoz, N.A., Aramendía, I., Tomassini, R. L., and Kay, R.F. 2018. The outstanding Río Chalía (=Sehuen) outcrops of the Santa Cruz Formation 
(early Miocene, Burdigalian) and its fossil vertebrate content. Publicación Electrónica de la Asociación Paleontológica Argentina, Suplemento de resúmenes 19: R85.

Vizcaíno, S.F., Bargo, M.S., and Fernicola, J.C. 2013. Expediciones paleontológicas durante los Siglos XIX y XX a la Formación Santa Cruz (Mioceno Inferior, Patagonia) y destino de los fósiles. $3^{\circ}$ Congreso Argentino de Historia de la Geología (Salta), Actas: 231246.

Vizcaíno, S.F., Kay, R.F., and Bargo, M.S. 2012. Early Miocene Paleobiology in Patagonia: High-latitude Paleocommunities of the Santa Cruz Formation. Cambridge University Press, Cambridge, 378 p.

Zapata, L. 2018. [Estudio paleoambiental de la Formación Santa Cruz (Mioceno inferior-medio) entre los ríos Coyle y Gallegos, Patagonia Austral, Argentina. Ph.D Thesis, Facultad de Ciencias Naturales y Museo, Universidad Nacional de La Plata, 304 p. Unpublished.].
Zonneveld, J.P., Lavigne, J.M., Bartels, W.S., and Gunnell, G.F. 2006. Lunulichnus tuberosus ichnogen. andichno sp. nov. from the Early Eocene Wasatch Formation, Fossil Butte National Monument, Wyoming: an arthropod-constructed trace fossil associated with alluvial firmgrounds. Ichnos 13: 87-94.

Doi: 10.5710/PEAPA.27.07.2019.294

Recibido: 05 de abril 2019

Aceptado: 27 de julio 2019 